Article

\title{
Incorporating Multi-Scale, Spectrally Detected Nitrogen Concentrations into Assessing Nitrogen Use Efficiency for Winter Wheat Breeding Populations
}

\author{
Raquel Peron-Danaher ${ }^{1,2,3}$, Blake Russell ${ }^{4}$, Lorenzo Cotrozzi ${ }^{1,5,+} \mathbb{D}$, Mohsen Mohammadi ${ }^{4}(\mathbb{D}$ \\ and John J. Couture $1,3,5, *$ (D)
}

1 Department of Entomology, Purdue University, West Lafayette, IN 47906, USA; rperon@purdue.edu (R.P.-D.); lorenzo.cotrozzi@agr.unipi.it (L.C.)

2 Interdisciplinary Life Science Education Program, Purdue University, West Lafayette, IN 47906, USA

3 Center for Plant Biology, Purdue University, West Lafayette, IN 47906, USA

4 Department of Agronomy, Purdue University, West Lafayette, IN 47906, USA; russe109@purdue.edu (B.R.); mohamm20@purdue.edu (M.M.)

5 Department of Forestry and Natural Resources, Purdue University, West Lafayette, IN 47906, USA

* Correspondence: couture@purdue.edu

+ Current Address: Department of Agriculture, Food and Environment, University of Pisa, 56124 Pisa, Italy.

check for updates

Citation: Peron-Danaher, R.; Russell, B.; Cotrozzi, L.; Mohammadi, M.; Couture, J.J. Incorporating Multi-Scale, Spectrally Detected Nitrogen Concentrations into Assessing Nitrogen Use Efficiency for Winter Wheat Breeding Populations. Remote Sens. 2021, 13, 3991. https:// doi.org/10.3390/rs13193991

Academic Editors: Yuxin Miao

Received: 1 September 2021

Accepted: 26 September 2021

Published: 9 October 2021

Publisher's Note: MDPI stays neutral with regard to jurisdictional claims in published maps and institutional affiliations.

Copyright: (c) 2021 by the authors. Licensee MDPI, Basel, Switzerland. This article is an open access article distributed under the terms and conditions of the Creative Commons Attribution (CC BY) license (https:// creativecommons.org/licenses/by/ $4.0 /)$.

\begin{abstract}
Annually, over 100 million tons of nitrogen fertilizer are applied in wheat fields to ensure maximum productivity. This amount is often more than needed for optimal yield and can potentially have negative economic and environmental consequences. Monitoring crop nitrogen levels can inform managers of input requirements and potentially avoid excessive fertilization. Standard methods assessing plant nitrogen content, however, are time-consuming, destructive, and expensive. Therefore, the development of approaches estimating leaf nitrogen content in vivo and in situ could benefit fertilization management programs as well as breeding programs for nitrogen use efficiency (NUE). This study examined the ability of hyperspectral data to estimate leaf nitrogen concentrations and nitrogen uptake efficiency (NUpE) at the leaf and canopy levels in multiple winter wheat lines across two seasons. We collected spectral profiles of wheat foliage and canopies using full-range (350-2500 nm) spectroradiometers in combination with leaf tissue collection for standard analytical determination of nitrogen. We then applied partial least-squares regression, using spectral and reference nitrogen measurements, to build predictive models of leaf and canopy nitrogen concentrations. External validation of data from a multi-year model demonstrated effective nitrogen estimation at leaf and canopy level $\left(R^{2}=0.72,0.67\right.$; root-mean-square error (RMSE) $=0.42,0.46$; normalized RMSE $=12,13$; bias $=-0.06,0.04$, respectively). While NUpE was not directly well predicted using spectral data, NUpE values calculated from predicted leaf and canopy nitrogen levels were well correlated with NUpE determined using traditional methods, suggesting the potential of the approach in possibly replacing standard determination of plant nitrogen in assessing NUE. The results of our research reinforce the ability of hyperspectral data for the retrieval of nitrogen status and expand the utility of hyperspectral data in winter wheat lines to the application of nitrogen management practices and breeding programs.
\end{abstract}

Keywords: hyperspectral phenotyping; nitrogen use efficiency; partial least-squares regression; proximal sensing; spectroscopy; wheat

\section{Introduction}

Wheat is one of the most widely cultivated cereal crops in the world. Annually, 220 million ha of wheat are planted, producing over 670 million tons of grain, which is mostly used as a food source for humans and animals [1]. Because of the widespread consumption, this cereal plays an essential role in global food security, representing $20 \%$ 
of total caloric intake and protein ingestion for many [1]. Recent studies have shown a continued increase in wheat consumption by humans, which established a new record in 2018-2019 of approximately 602 million metric tons (MMT) of wheat consumed worldwide [2]. Additionally, projections estimate that the demand for wheat will increase by nearly $60 \%$ within the next 30 years due to projected human population growth [3]. This predicted increase in consumption poses a significant challenge for wheat breeders and producers, especially considering the estimated decrease in available areas for cultivation and an increase of extreme weather events [1].

The USA predominantly produces winter wheat ( $70-80 \%$ of total wheat planted) due to the cultivars' high yield potential [4]. Winter wheat is planted in late summer and early fall, then germinates and establishes roots, and has a vernalization period in the winter, where a temperature below $8{ }^{\circ} \mathrm{C}$ is necessary to induce flowering [5]. Wheat grain is composed of approximately $12-15 \%$ of protein [6], and consequently wheat needs a high rate of nitrogen uptake that in turn requires an elevated rate of nitrogen fertilization for optimal productivity [7]. The high fertilization rate is due to the low efficiency of nitrogen uptake and remobilization to grain during filling [8,9]. Consequently, a large amount of nitrogen is applied in fields annually, over 100 million tons globally, to ensure optimal wheat productivity [10], and wheat fertilization represents nearly $20 \%$ of the total fertilizer input used in crop plants globally [11]. The high amount of fertilizer input required for optimal wheat production, however, can harm the environment and represents a substantial production cost for farmers $[1,9,10,12,13]$. Developing approaches to quantify wheat nitrogen status in the field can aid in determining optimal fertilizer inputs which will help mitigate the adverse effects of under- and over-fertilization.

In addition to improving the management of field-based fertilization, selecting lines with enhanced nitrogen use efficiency (NUE) can help mitigate the high demand by wheat for nitrogen fertilizer inputs. NUE is defined as the ability of a plant to increase grain dry-weight yield per unit of nitrogen uptake from the soil $[14,15]$ and is composed of two key elements: nitrogen uptake efficiency (NUpE) and nitrogen utilization efficiency (NUtE) [16]. Monitoring nitrogen fertilizer input, as well as quantifying NUE, requires accurate nitrogen determination in plant tissue, especially at the scale for in-field monitoring and assessing agronomic breeding populations. Traditional methods are labor-intensive and time-consuming, requiring tissue collection and chemical analysis. These analyses also provide temporally limited information, and because of the costs, measurements are collected infrequently, limiting information about nutrient dynamics throughout a growing season. Thus, there is a critical need to develop more rapid and efficient methods for assessing NUE, in vivo and in situ, to assist breeding programs [17].

Recent advances in sensor-based approaches for monitoring plant status have revealed promising outcomes [18], and hyperspectral reflectance has gained considerable attention by demonstrating the ability to estimate plant chemical composition. The ability of hyperspectral data to confirm plant chemical composition relies on variation in the absorption of light due to differential patterns of vibrational excitation of molecular bonds, primarily C-H, N-H, and O-H bonds, at specific wavelengths in the visible (VIS; 400-700 nm), near-infrared (NIR; 700-1100 nm), and short-wave infrared (SWIR; 1100-2500 nm) ranges. Thus, variations in plant spectral profiles are determined by the chemical and physical composition of the vegetation $[19,20]$, and the use of spectral data from vegetation, combined with mathematical methods, has been demonstrated to be an efficient approach to accurately predict plant traits, such as water status, physiological processes, and primary and secondary metabolites [21-33].

While previous studies showed that hyperspectral data applied to nitrogen assessment in wheat is an efficient method for estimating nitrogen concentrations in wheat $[22,23,29,32,34-36]$, those studies were mostly conducted using a single measurement approach and often did not explore either the scalability of hyperspectral data over measurement scales (e.g., leaf vs. canopy) or the transferability of models across seasons [31]. Furthermore, the ability of spectral data to scale across different genotypes 
within species and years is not well understood and needs further study to identify the range of applications for the use of hyperspectral data in agronomic practices [30,31,37].

To address these knowledge gaps, we examined the ability of hyperspectral data to identify traits related to nitrogen dynamics in different wheat lines, across two growing seasons, and assessed the ability of hyperspectral data in estimating NUpE in a wheat breeding population. Specifically, we (1) developed predictive models using hyperspectral data to estimate nitrogen concentration at leaf and canopy levels, (2) assessed model performance to estimate nitrogen concentration across different wheat lines and growing seasons, (3) estimated NUE directly from spectral data, and (4) used predicted nitrogen values to calculate NUE components and test the accuracy of this method with conventional NUE calculations.

\section{Materials and Methods}

\subsection{Experimental Design}

This project was conducted at the Agronomy Center for Research and Education at Purdue University (ACRE), West Lafayette, IN, USA $\left(40^{\circ} 47^{\prime} 10^{\prime \prime} \mathrm{N},-87^{\circ} 01^{\prime} 04^{\prime \prime} \mathrm{W}\right.$, annual precipitation: $1047 \mathrm{nn}$ /year, average annual temperature: $11.5^{\circ} \mathrm{C}$ ). The soil type at ACRE is described as a combination of: Rockfield silt loam, Fincastle silt loam, and Toronto silt loam (USDA Web Soil Survey). Additional information about detailed soil characteristics can be found in Appendix A, Table A1. The 2017 experiment was planted in September 2016 and included four different wheat lines, showing a range of yield performance under nitrogen fertilization regimes, selected from the Purdue soft-red winter wheat breeding program, listed in Appendix B, Table A2. The 2018 experiment was planted in October 2017 and included 32 different lines, also selected from the Purdue soft-red winter wheat breeding program, showing a range of yield performance under nitrogen fertilization regimes, and listed in Appendix B, Table A2. The goal of this paper was to determine the ability of hyperspectral data to estimate foliar nitrogen levels and to assess the utility of the approach in breeding wheat lines for NUE and not to assess responses of individual wheat lines to different fertilizer levels. Specific information about the responses of different wheat lines to variable fertilization and the resulting NUE can be found in [38].

In both years, all wheat lines were planted in eight replicate plots for each genotype: four plots with baseline fertilization and four plots with baseline and supplemental fertilization. Plot dimensions were $1.22 \mathrm{~m} \times 3.05 \mathrm{~m}$ and contained seven rows with $15 \mathrm{~cm}$ intervals; seeds were planted at a density of 370 seeds $\mathrm{m}^{-2}$. In both years, prior to planting, all plots were fertilized with monoammonium phosphate $\left(\left(\mathrm{NH}_{4}\right) \mathrm{H}_{2} \mathrm{PO}_{4}(\mathrm{~N}, \mathrm{P}, \mathrm{K}: 11-52-0)\right)$ at a rate of $24.6 \mathrm{~kg} \mathrm{ha}^{-1}$. In the spring following planting, four replicates of each line received supplemental fertilizer treatments with urea (N, P, K: 46-0-0) treated with Limus (BASF, Germany) during the stem elongation growth stage (Zadoks 30) at a rate of $112.09 \mathrm{~kg} \mathrm{ha}^{-1}$ establishing a low, consisting of lines that were fertilized only prior to planting, and a high, consisting of lines fertilized both prior and after planting, fertilization treatments. Detailed soil composition is described in Appendix A, Table A1.

\subsection{Spectral and Reference Tissue Collections}

\subsubsection{Data Collection 2017}

Hyperspectral data were collected from leaf and canopy levels using full-range spectroradiometers (HR-1024i, Spectra Vista Corporation, Poughkeepsie, NY, USA). Collections were carried out on all four wheat lines at six different time points (TPs) over one growing season. Each TP represented a different physiological plant stage: booting (TP1-26/04/2017; Zadoks 45), onset of heading (TP2-08/05/2017; Zadoks 50), heading (TP3-15/05/2017; Zadoks 58), flowering (TP4-22/05/2017; Zadoks 60), post-anthesis (TP506/06/2017; Zadoks 68), and maturity (TP6-12/06/2017; Zadoks 91). Each plot was subdivided into three subplots, and spectral and foliar collections were carried out in one randomly selected subplot within each plot. A total of 288 samples, with paired spectral and foliar measurements, were collected and distributed as follows: 32 samples from TP1 
and TP2 (4 lines $\times 2$ fertilization treatments $\times 4$ plots $=32)$ and 64 samples from TP3, TP4, TP5, and TP6 each $(4$ lines $\times 2$ fertilization treatments $\times 8$ plots $\times 4$ time points $=256)$. During the first two time points (TP1 and TP2), weather and logistical constraints limited us to sampling only four of the eight total plots. Canopy reflectance measurements were conducted between 11:00 and 13:00 h., under clear sky conditions, using an eight-degree foreoptic (representing approximately a $12 \mathrm{~cm}^{-2}$ area) mounted to a tripod at one meter above the canopy, with a foreoptic angle approximately at nadir of the target. Following the canopy measurements, four flag leaves were collected and stored in separate paper bags on ice. After returning to the laboratory $(<2 \mathrm{~h})$, leaf reflectance was measured on the adaxial leaf surface, using the same spectroradiometer but fitted with a fiber optic cable attached to a plant probe with a leaf clip, containing an internal halogen light source fitted in a lens tube adapter for small spot (ideal for viewing samples with narrow area, such as wheat leaves). Relative reflectance for both leaf and canopy measurements was determined by dividing vegetation radiance by the radiance of a 99\% reflective white panel (Spectralon, Labsphere, North Sutton, NH, USA) that was collected either just above the canopy, for canopy measurements, or mounted within the internal leaf clip, for leaf measurements, measured every 15 or 12 spectral collections for leaf and canopy measurements, respectively. After measurements, leaf samples were flash-frozen in liquid nitrogen and stored in a freezer at $-20{ }^{\circ} \mathrm{C}$ until they were oven-dried at $90{ }^{\circ} \mathrm{C}$ for seven days. After reaching a constant dry mass, samples were ground for chemical analysis using a ball mill.

\subsubsection{Data Collection 2018}

Hyperspectral data were collected from leaf and canopy levels from all 32 wheat lines at a single time point: heading and the beginning of flowering (from 24/05/2018 to 06/06/2018; Zadoks 58-60). Each plot was subdivided into two subplots, and spectral and foliar collections were carried out in one randomly selected subplot within each plot for spectral and leaf collection. The reason for this reduction in subplot sampling was to reduce sampling time so samples were of comparable growth stages. A total of 128 samples with paired spectral and foliar measurements were collected (32 lines $\times 2$ treatment $\times 2$ plots $=128$ ). The sample selection for nitrogen analysis was carried out assigning random samples from subplots collected across all genotypes and both treatments, and the spectral data collection and tissue sampling and processing for leaf and canopy measurements followed the same protocol as described in the 2017 data collection.

\subsection{Standard Nitrogen Analysis}

Analysis of nitrogen concentrations from foliar tissue collected from both years was performed using a Thermo Finnigan Flash 1112 elemental analyzer (San Jose, CA, USA). Atropine (CE Elantech, Lakewood, NJ, USA) was used as a standard [39,40]. The total leaf nitrogen concentration, in percentage dry mass, for the 2017 and 2018 datasets, ranged from 0.64 to 4.85 and 1.24 to 4.88 , respectively.

\subsection{Chemometric Modeling}

We generated chemometric models to predict nitrogen concentration in wheat from spectral data using partial least-squares regression (PLSR) [41,42]. In cases where predictor variables are highly correlated and outnumber response variables, such as often the case with hyperspectral data, classical regression techniques can produce unreliable beta coefficient estimates [42]. In contrast to standard regression approaches, PLSR reduces many inter-correlated predictor variables into relatively few, uncorrelated latent variables and is a preferred method in chemometrics [29,43-48]. The number of latent variables included in each model was determined by the reduction of the predicted residual error sum of squares (PRESS) statistic [49] following leave-one-out (LOO) cross-validation. The latent variables were then combined into a linear model to predict nitrogen concentrations.

To avoid the influence of canopy geometry and solar intensity during canopy measurements and to optimize PLSR models, reflectance data were vector-normalized [50]. 
The first derivative of spectral data was then calculated on the normalized reflectance data to highlight spectral differences for both leaf and canopy measurements. The wavelength range $400-2400 \mathrm{~nm}$ was used in both leaf and canopy models to capture absorption features related to both protein and chlorophyll content [19]. When using canopy spectral data, the wavelength region between 1800 and $2000 \mathrm{~nm}$ was omitted to remove the noise caused by atmospheric water absorption. Preliminary models identified poorly predicted outliers, detected by elevated reflectance in the visible wavelength region, spectral jumps that occur when the leaf clip is not fully engaged, or inconsistencies or errors in the reference data $[29,48,50-58]$. Outliers removed accounted for approximately 10 and $15 \%$ of the dataset for leaf and canopy collections, respectively.

For the 2017 data, we evaluated the model performance by conducting 500 randomized permutations of the entire 2017 dataset using 70\% of the data, divided into 80:20 split for calibration and cross-validation, respectively, with the remaining 30\% held out for external validation. For each permutation, we tracked the model goodness of fit $\left(R^{2}\right)$, overall error rate (root-mean-square error, RMSE), and normalized root-mean-square error (NRMSE) over the data range together with a bias to assess model performance when applied to the validation dataset. These randomized analyses generated a distribution of fit statistics allowing for the assessment of model stability as well as uncertainty in model predictions. We also determined the contribution of individual wavelength for the PLSR using the variable importance for the projection (VIP) selection statistic and standardized (i.e., centered and scaled) coefficients selection statistics, which explain the contribution of a single wavelength for the variance in the latent variables [44,58]. The modeling approach was performed using the 'pls' package in R (www.r-project.org accessed on 2 October 2019).

To assess cross-year transferability of spectral models, we applied models that were developed to predict nitrogen concentrations in 2017 to the spectral data collected in 2018. To determine if we could improve the model fit by adding data collection in 2018, we included $50 \%$ of the reference data (spectral data that had a paired reference nitrogen measurement) collected in 2018 (64 samples) and created a cross-year model, following the same modeling approach described above, and used the remaining $50 \%$ of the reference data (64 samples) collected in 2018 as external validation.

Categorization of Standardized Coefficients and VIP within Regions of Chlorophyll and Protein Absorption Features

To align spectral features with chlorophyll and protein absorption features, we categorized wavelength coefficients and VIP statistics (Appendix D, Tables A4 and A5) having a higher contribution to model performance into general regions of literature-published chlorophyll and protein absorption features. First, we averaged standardized coefficients and VIP values every $30 \mathrm{~nm}$ starting at $400 \mathrm{~nm}$ to account for multicollinearity. Then, we ranked the top 30 averaged standardized coefficient values. For the VIP statistic, we excluded all values that were below 0.8 , as suggested by [41], then averaged the VIP values as we did for coefficients, and then ranked the top 30 VIP values. Next, we selected literature-published chlorophyll and protein absorption features (Appendix C, Table A3) and binned wavelengths $40 \mathrm{~nm}$ on center of the published wavelength peak (i.e., $20 \mathrm{~nm}$ before and $20 \mathrm{~nm}$ after the described peak). This process was carried out to capture minor absorption features associated with chlorophyll and protein outside of the singular wavelength absorption feature. Finally, we identified averaged wavelength coefficients and VIP values that fell within the binned values for each chlorophyll and protein absorption feature range (Appendix D, Tables A6-A8).

\subsection{NUE Quantification}

We used two approaches to investigate the potential of spectral data to benefit NUE estimation. First, we tested the ability of spectral data to directly predict NUpE, following a similar chemometric modeling protocol described above, with the exception that we used only LOO cross-validation. We used this approach because the logistical constraints of collecting the biomass and chemical data to calculate NUpE, a component of NUE, limited 
the number of samples we were able to collect, and the total number of samples used in this analysis was considerably smaller $(n=39)$ than the number of samples collected for previous chemometric modeling of nitrogen concentrations. Second, we calculated NUpE using spectrally predicted nitrogen to test the accuracy of predicting component processes of NUE using spectral data. Reference NUpE was calculated using the nitrogen straw values, and estimated NUpE was calculated by substituting mid-season nitrogen values predicted by spectral models for straw values. NUpE was calculated as the following:

$$
N U p E=\frac{\text { Grain N }+ \text { Straw } N}{N \text { Supplied }}
$$

where Grain $N$ is the nitrogen concentration in the grain, Straw $N$ is the whole-plant (leaves, stems, tillers, organs) nitrogen level, and N Supplied is the quantity of nitrogen applied via fertilizer $\left(\mathrm{kg} \mathrm{N} \mathrm{ha}^{-1}\right)$ [38].

\section{Results}

\subsection{Chemometric Models}

\subsubsection{Modeling and Cross-Year Validation 2017}

The 2017 model accurately predicted nitrogen at both leaf and canopy levels, although there was a decline in external validation performance (Table 1, Figure 1), and these declines were comparable.

Table 1. Performance metrics of the 2017 model: number of latent variables (LVs), goodness of fit $\left(R^{2}\right)$, root-mean-square error (RMSE), normalized root-mean-square error (NRMSE), and bias for calibration (C), cross-validation (CV), and external validation (EV). Data generated via cross-validation using 500 random permutations of the dataset with $70 \%$ of the total data divided into 80:20 split for $\mathrm{C}$ and $\mathrm{CV}$, respectively, for models predicting nitrogen concentrations from wheat foliage using hyperspectral data. EV was generated by applying coefficients generated in the C:CV approach to the $30 \%$ of the data excluded from the C:CV approach. Data shown as mean \pm standard deviation.

\begin{tabular}{|c|c|c|c|c|c|c|c|c|c|c|c|}
\hline \multirow{2}{*}{$\begin{array}{l}\text { Data } \\
\text { Level }\end{array}$} & \multirow[t]{2}{*}{ LV } & \multicolumn{3}{|c|}{$\mathbf{R}^{2}$} & \multicolumn{2}{|c|}{ RMSE } & \multicolumn{2}{|c|}{$\underset{(\%)}{\text { NRMSE }}$} & \multicolumn{3}{|c|}{ Bias } \\
\hline & & $\mathrm{C}$ & CV & EV & $\mathrm{C}$ & CV & EV C & CVEV & $\mathrm{C}$ & CV & EV \\
\hline Leaf & 5 & $0.90 \pm 0.00$ & $0.84 \pm 0.02$ & 0.71 & $0.24 \pm 0.01$ & $0.31 \pm 0.02$ & 0.458 & 1014 & $4.10 \times 10^{-18} \pm 0.02$ & $-0.0002 \pm 0.05$ & -0.009 \\
\hline Canopy & 6 & $0.87 \pm 0.01$ & $0.85 \pm 0.02$ & 0.73 & $0.27 \pm 0.01$ & $0.3 \pm 0.02$ & 0.429 & $9 \quad 13$ & $4.89 \times 10^{-18} \pm 0.02$ & $-0.0015 \pm 0.04$ & 0.003 \\
\hline
\end{tabular}

(a)

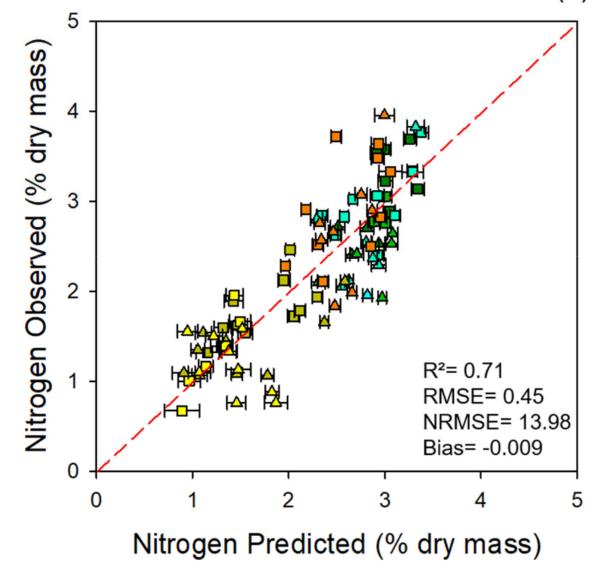

(b)

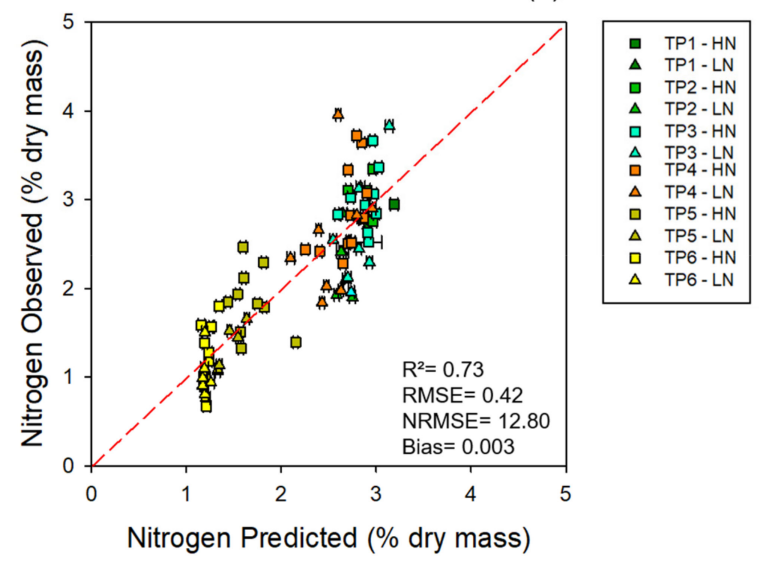

Figure 1. Models for 2017: observed vs. predicted external validation values of nitrogen levels from the 2017 dataset. (a) External validation of nitrogen estimates using leaf-level spectral measurements. (b) External validation of nitrogen estimates using canopy-level spectral measurements. Error bars for estimated values represent the standard deviation generated from 500 model permutations using an 80:20 calibration:cross-validation approach. Dashed line: 1:1 relationship. $R^{2}$ : model goodness of fit; RMSE: root-mean-square error (\% dry mass); NRMSE: normalized root-mean-square error (\%). TP1, time point 1 = booting (Zadoks 45); TP2, time point 2 = onset of heading (Zadoks 50); TP3, time point 3 = heading (Zadoks 58); TP4, time point $4=$ flowering (Zadoks 60$)$; TP5, time point $5=$ post-anthesis (Zadoks 68); TP6, time point $6=$ maturity (Zadoks 91 ). 
(a)

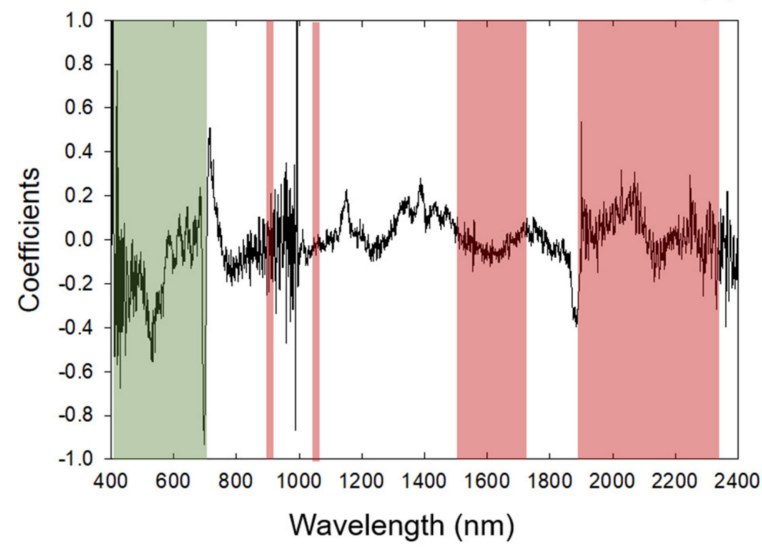

(c)

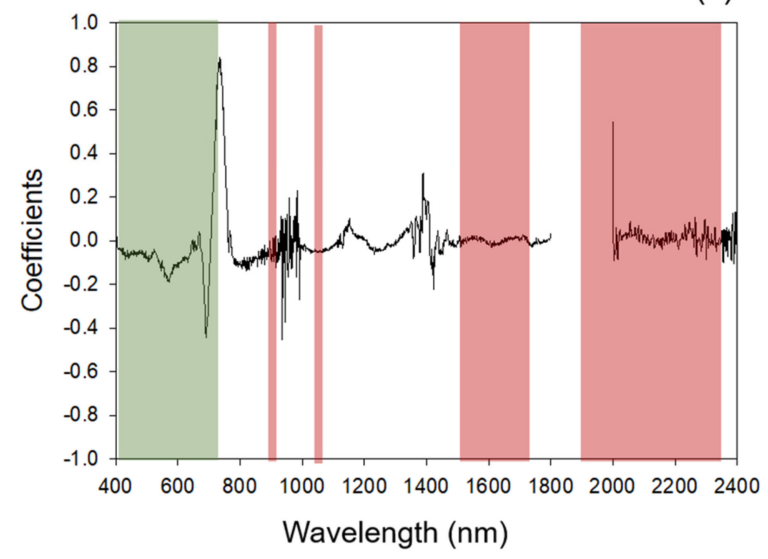

(b)

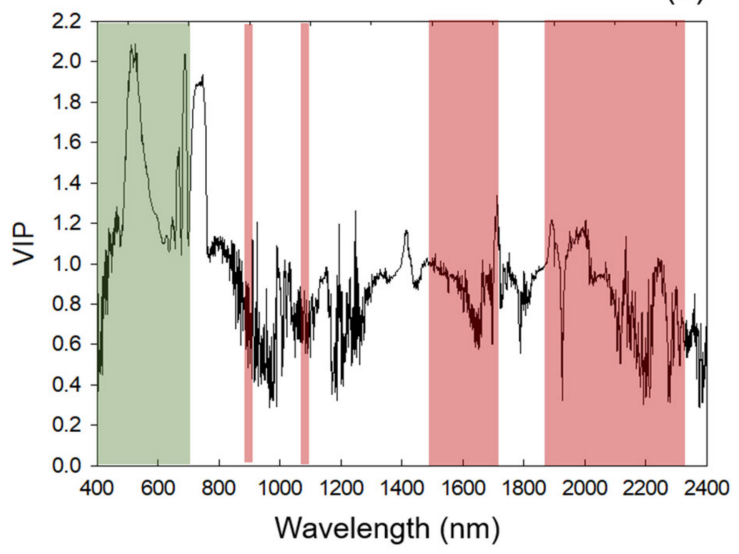

(d)

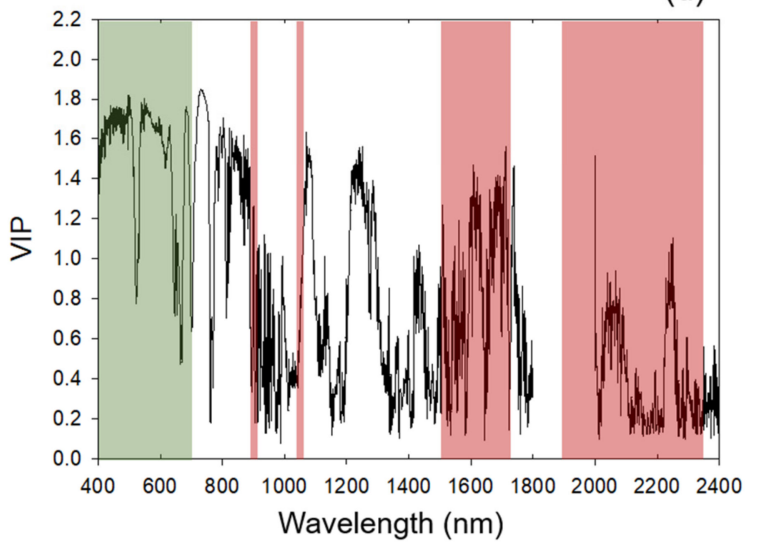

Figure 2. Standardized coefficients and variable importance for the projection (VIP) selection for 2017 models. $(\mathbf{a}, \mathbf{c})$ Standardized coefficients of 2017 models for leaf-level and canopy-level measurements, respectively; (b,d) VIP of 2017 models for leaf-level and canopy-level measurements, respectively. Shaded areas: regions of absorption feature present between 400 and $2400 \mathrm{~nm}$ for chlorophyll (green) and protein (red). Specific absorption features within these regions are listed in Appendix C Table A3.

The 2017 nitrogen prediction models applied to the 2018 dataset revealed a skewed nitrogen prediction (Figure 3), with a decrease in $R^{2}$ ( 0.71 to 0.69 and 0.73 to 0.45 for leaf and canopy models, respectively), an overall change in RMSE ( 0.45 to 0.41 and 0.42 to 0.52 for leaf and canopy models, respectively) and NRMSE (14 to 11 and 13 to 12 for leaf and canopy models, respectively), and an increase in bias ( 0.009 to -0.34 and 0.003 to -1.17 for leaf and canopy estimates, respectively).

\subsubsection{Multi-Year Models: Combining 2017 and 2018 Datasets}

The multi-year model showed improved results compared with the cross-year predictions. The multi-year model yielded an accurate predictive model for nitrogen for leaf and canopy levels (Table 2) with good external validation (Figure 4). 
Similar to the 2017 models, the multi-year models presented peaks for standardized coefficients and VIP profiles for nitrogen prediction in spectral regions with known chlorophyll and protein absorption features (Figure 5, Appendix D Tables A7 and A8). Multi-year coefficients and VIP values were highly correlated with 2017 outputs for leaf (Pearson's correlation $r=0.64, p<0.001$, and $0.94, p<0.001$, for coefficients and VIP values, respectively, $n=2001$ ) and canopy (Pearson's correlation $r=0.68, p<0.001$, and $0.98, p<0.001$, for coefficients and VIP values, respectively, $n=1801$ ) models. Standardized coefficients and VIP statistics generally aligned with wavelengths at approximately 430, 500, 630 700, 790, 900, 1000, 1300, 1400, 1900, 2000, 2100, 2300, 2350 and $2390 \mathrm{~nm}$ (Figure 5 and Appendix D Tables A7 and A8). Again, similar to the 2017 models, the multi-year leaf-level models leveraged relatively more coefficients in the SWIR region compared to the canopy model, which had more coefficients in the VNIR region (Appendix D Table A8).

(a)
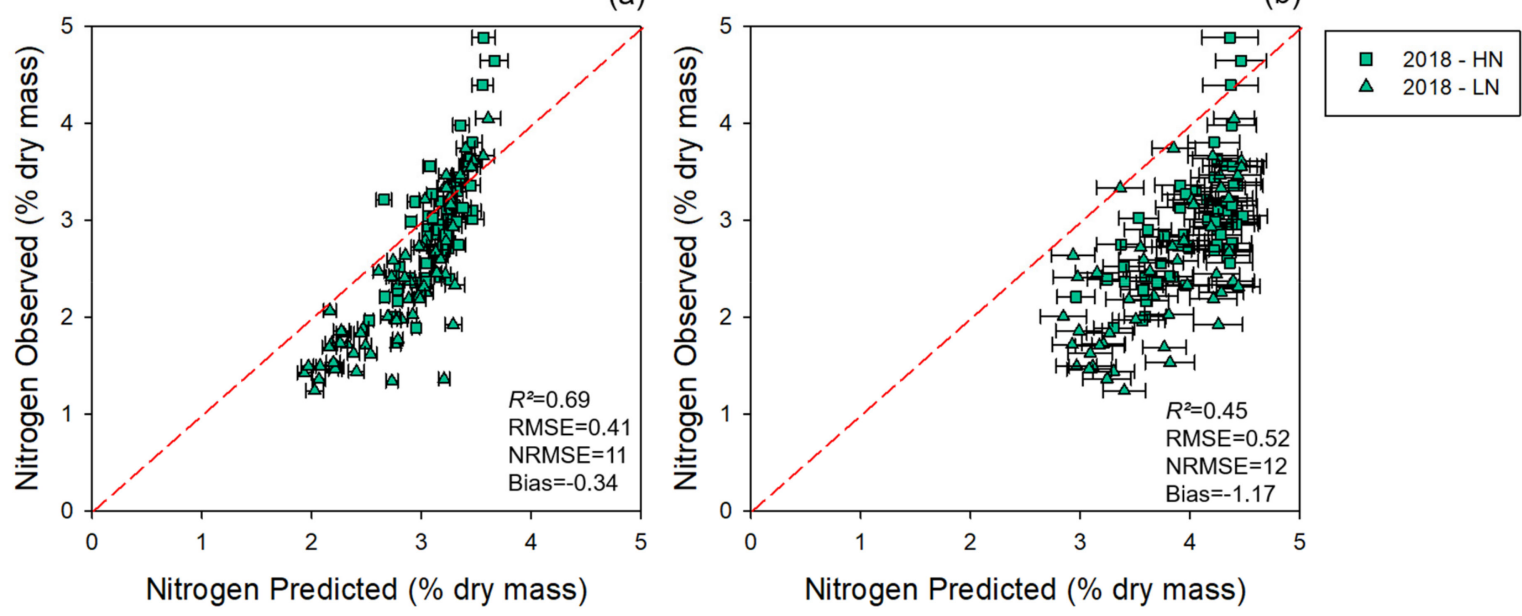

Figure 3. Observed vs. predicted values of nitrogen level estimates for 2018 collections using coefficients from the 2017 model. (a) Estimates generated using leaf-level spectral measurements; (b) estimates generated using canopy-level spectral measurements. Error bars for estimated values represent the standard deviation generated from 500 model permutations using an 80:20 calibration:cross-validation approach. Dashed line: 1:1 relationship. $R^{2}$ : model goodness of fit; RMSE: root-mean-square error; NRMSE: normalized root-mean-square error.

Table 2. Multi-year models' performance: number of latent variables (LVs), model goodness of fit $\left(R^{2}\right)$, root-mean-square error (RMSE), normalized root-mean-square error (NRMSE), and bias for calibration (C), cross-validation (CV), and external validation $(\mathrm{EV})$. Data generated via cross-validation using 500 random permutations of the dataset with $70 \%$ of the total data divided into 80:20 split for $\mathrm{C}$ and $\mathrm{CV}$, respectively, for models predicting nitrogen concentrations from wheat foliage using hyperspectral data. EV was generated by applying coefficients generated from the C:CV approach to the $30 \%$ of the data excluded from the C:CV approach. Data shown as mean \pm standard deviation.

\begin{tabular}{|c|c|c|c|c|c|c|c|c|c|c|c|c|}
\hline \multirow{2}{*}{$\begin{array}{l}\text { Data } \\
\text { Level }\end{array}$} & \multirow[t]{2}{*}{ LV } & \multicolumn{3}{|c|}{$\mathbf{R}^{2}$} & \multicolumn{3}{|c|}{ RMSE } & \multicolumn{3}{|c|}{$\underset{(\%)}{\text { NRMSE }}$} & \multicolumn{2}{|l|}{ Bias } \\
\hline & & $\mathrm{C}$ & CV & EV & $\mathrm{C}$ & CV & EV & C & & EV & $\mathrm{C}$ & CV \\
\hline Leaf & 6 & $0.89 \pm 0.01$ & $0.84 \pm 0.01$ & 0.72 & $0.01 \pm 0.01$ & $0.32 \pm 0.01$ & 0.42 & 7 & 101 & 12 & $-1.2 \times 10^{-17} \pm 0.00$ & $-0.0043-0.06$ \\
\hline Canopy & 5 & $0.87 \pm 0.01$ & $0.84 \pm 0.02$ & 0.67 & $0.26 \pm 0.01$ & $0.29 \pm 0.02$ & 0.46 & 9 & 10 & 13 & $5.98 \times 10^{18} \pm 0.00$ & -0.00160 .04 \\
\hline
\end{tabular}

\subsection{NUE Prediction}

Models directly predicting NUpE were less accurate than the models predicting nitrogen. NUpE models presented an average $R^{2}$ of 0.52 and 0.37 , an average RMSE of 0.30 and 0.28 , an average NRMSE of 8 and 9 , and an average bias of 0.01 and 0.01 for leaf and canopy levels, respectively (Figure 6). NUpE calculations were strongly correlated at both leaf and canopy levels (Pearson's correlation $r=0.86, p<0.001, n=18$, and 0.76, $p=0.004$, $n=12$, respectively) when we compared NUpE using reference nitrogen or nitrogen levels predicted by the multi-year model (Figure 7). We also found that using spectrally predicted 
nitrogen for $\mathrm{NUpE}$ calculations resulted in an overestimation of $\mathrm{NUpE}$ values. Normalizing $\mathrm{NUpE}$ for both estimation and reference data, however, decreased bias by 95 and $93 \%$ and revealed a higher correlation with $r=0.93, p=0.001$, and bias $=0.11$ for leaf level and $r=0.87, p=0.0002$, and bias $=0.17$ for canopy level, respectively.
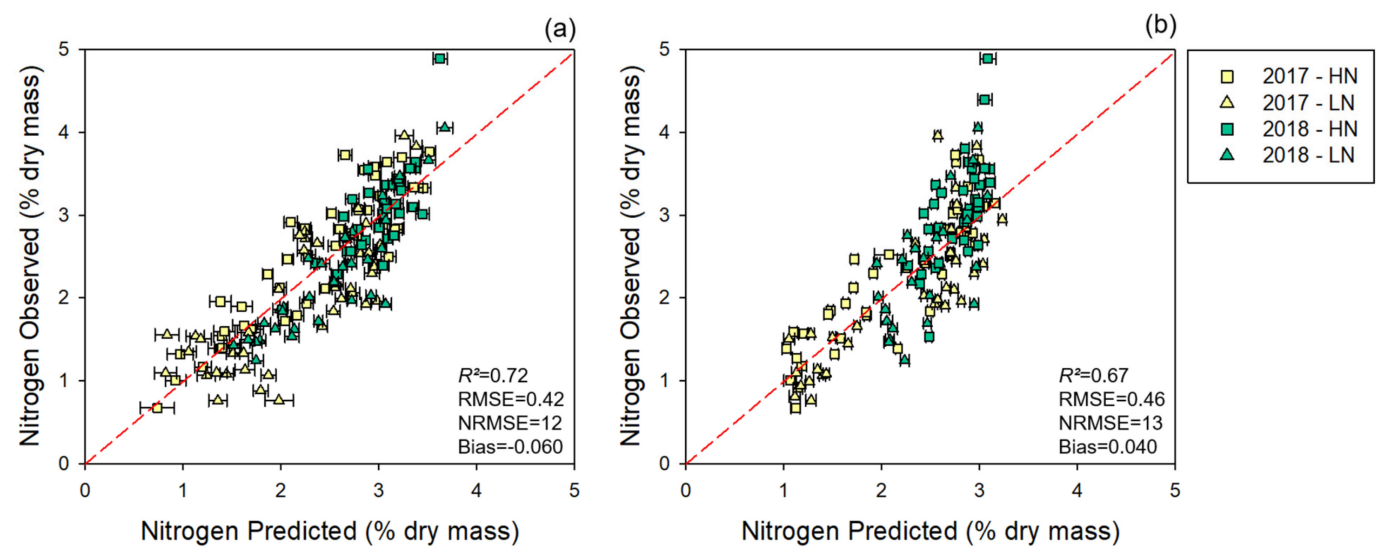

Figure 4. Multi-year models: observed vs. predicted external validation values of nitrogen levels derived from the multiyear dataset. (a) External validation of nitrogen estimates generated using leaf-level spectral measurements. (b) External validation of nitrogen estimates generated using canopy-level spectral measurements. 2017: 2017 dataset, 2018 : 2018 dataset. Error bars for estimated values represent the standard deviation generated from 500 model permutations using an 80:20 calibration:cross-validation approach. Dashed line: 1:1 relationship. $R^{2}$ : model goodness of fit; RMSE: root-mean-square error; NRMSE: normalized root-mean-square error.

(a)

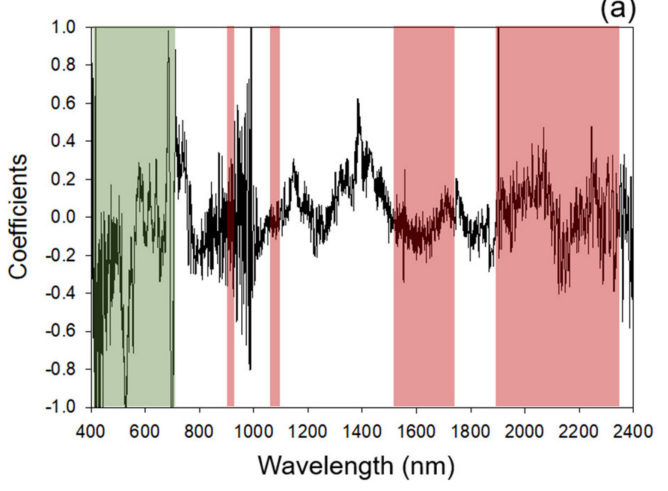

(c)

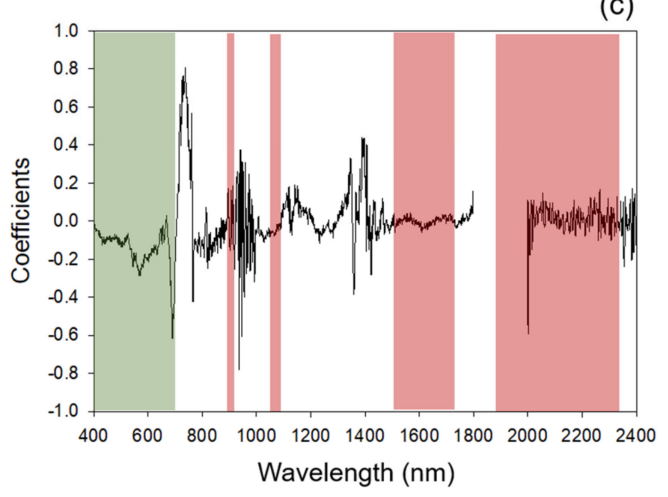

(b)

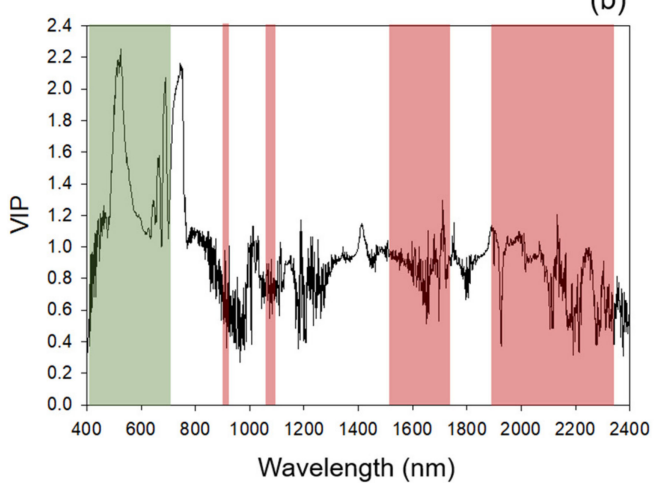

(d)

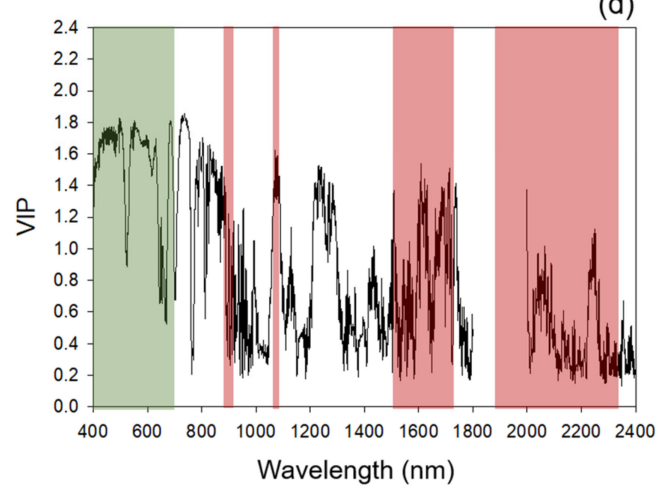

Figure 5. Multi-year models: standardized coefficients and variable importance for the projection (VIP) selection for multi-year models. (a,c) Standardized coefficients of the multi-year models for leaf-level and canopy-level measurements, respectively; (b,d) VIP of the multi-year models for leaf-level and canopy-level measurements, respectively. Shaded areas: absorption features present between 400 and $2400 \mathrm{~nm}$ for chlorophyll (green) and protein (red). Specific absorption features within these regions listed in Appendix C Table A3. 
(a)

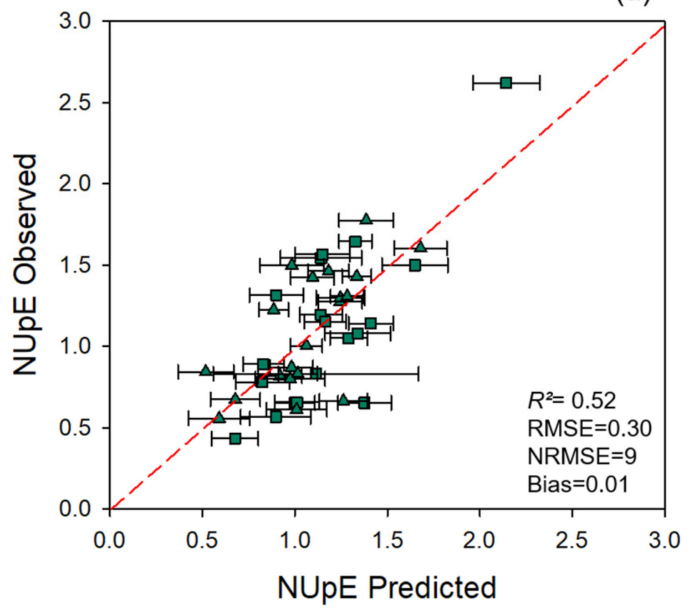

(b)

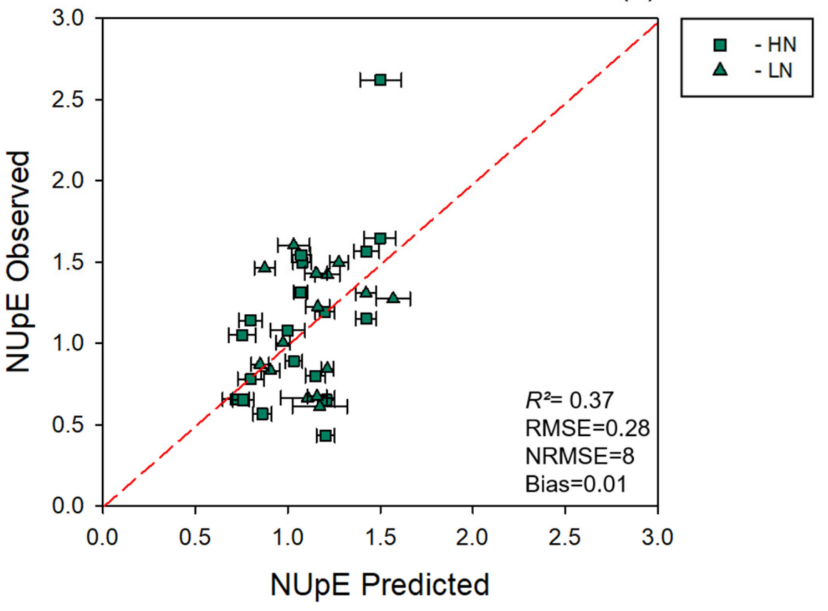

Figure 6. Observed vs. predicted values of NUpE estimated using spectral data. (a) Cross-validated NUpE estimates determined using leaf-level spectral measurements. (b) Cross-validated NUpE estimates determined using canopy-level spectral measurements. Error bars for estimated values represent the standard deviation generated from 500 model permutations using an 80:20 calibration:cross-validation approach. Dashed line: 1:1 relationship. $R^{2}$ : model goodness of fit; RMSE: root-mean-square error; NRMSE: normalized root-mean-square error.

(a)

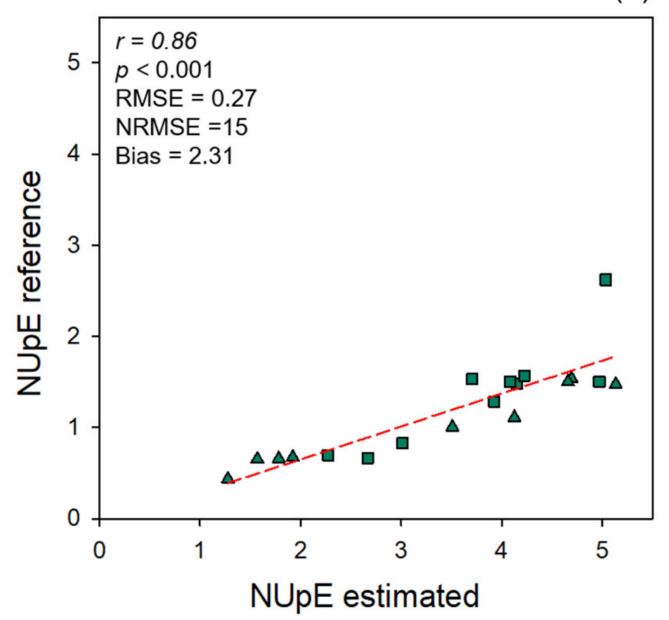

(b)

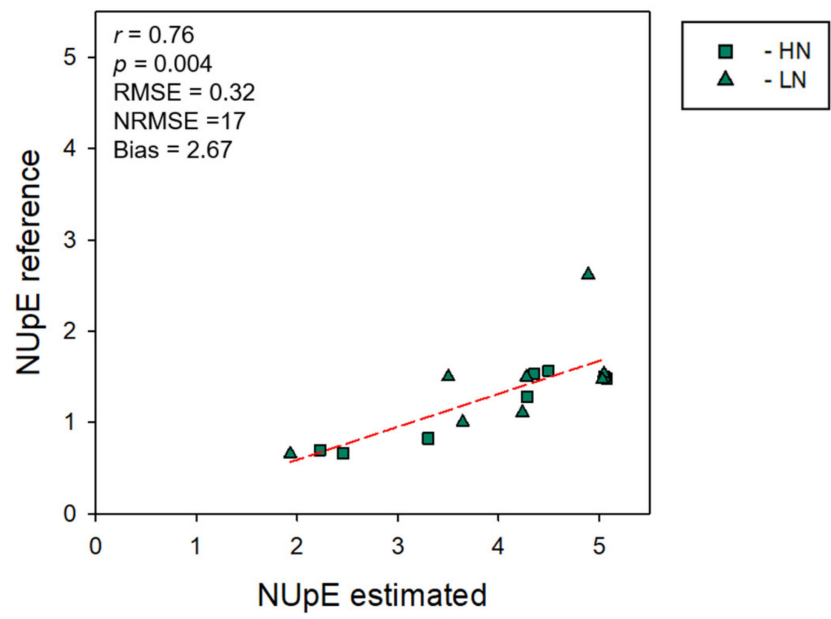

Figure 7. Relationships between nitrogen uptakes (NUpEs) calculated using either reference or estimated nitrogen values. (a) Leaf-level measurements, (b) canopy-level measurements. $R^{2}$ : model goodness of fit; RMSE: root-mean-square error; NRMSE: normalized root-mean-square error. NUpE reference: standard NUpE measurement. NUpE estimated: NUpE calculated using nitrogen predicted values as the input. Dashed line: 1:1 relationship.

\section{Discussion}

Wheat production has doubled in the last four decades, and the need to increase production of this globally important crop, while minimizing fertilization inputs, is critical. In this paper, we show that (1) hyperspectral data, collected at multiple different scales, can be used for estimation of foliar nitrogen levels in wheat, (2) updating of models to include a greater genetic variability and nitrogen range improves prediction accuracy, and (3) spectral estimates of foliar nitrogen, at different scales, can potentially be used as a replacement for reference data to identify NUE components in a breeding population.

The use of hyperspectral data to estimate plant traits, including nitrogen, is becoming more common with the expansion of precision and digital agriculture, and recent studies have demonstrated positive results for monitoring nitrogen status in several crops $[27,31,34,39,53-60]$. While several of these studies explored the ability of hyper- 
spectral data to access nitrogen content in crops, including winter wheat, most studies have focused on the VIS and NIR wavelength ranges, relying primarily on relationships with chlorophyll content to interpret nitrogen content [60]. It is possible that using multiple wheat stages over the season in the models from 2017 influenced the estimation outcomes because of changes in leaf color. However, the linkage between chlorophyll and nitrogen can vary among different ecosystems, environmental conditions, and biotic and abiotic stressors $[59,60]$. Methods that rely solely on chlorophyll content for nitrogen assessment can be misleading, especially in the context of nitrogen fertilization management, once several other factors lead to chlorophyll reduction in leaves, such as sulfur deficiency, vegetative stage of the plants, and disease [60], and thus measurements are likely more sensitive to changes in leaf color (i.e., green vs. senescent vegetation). Chlorophyll accounts for a smaller portion of nitrogen contained within leaves compared with protein (e.g., Rubisco), which can account for over $50 \%$ of nitrogen content in plant tissue [60-64]. Rubisco also is a principal source for nitrogen remobilization as well and is a key enzyme driving photosynthesis [61]. Full-spectrum data can leverage both chlorophyll and protein absorption features that are closely related to leaf nitrogen content. Our findings suggest that spectral data can accurately predict nitrogen at both leaf- and canopy-level measurements, corroborating with the findings of other studies $[27,29,31,60,61,64]$.

Our assessment of a single-season model revealed a high prediction accuracy for nitrogen in the 2017 leaf-level model. This response was likely bolstered by data collected across the growing season in 2017 that captured a wide range of nitrogen concentrations in leaves, especially at lower levels of nitrogen in mature leaves due to nitrogen remobilization [64]. The estimation of nitrogen from samples collected in 2018 using the model built solely from the model developed in 2017, however, revealed a decline in model performance when compared with the 2017-only model. We anticipated this decline because of the introduction of increasing genetic variability and a greater range of nitrogen and because we included a wider range of lines from the NUE breeding population used in 2017. A decline in model performance when transferring models across years to novel genetic material has been previously demonstrated [65]. We found that when the model was updated to capture the new cultivars and increased range of nitrogen levels (i.e., 2017 and 2018 multi-year model) performance returned to near-original performance. These outcomes highlight the importance of updating predictive spectral models as novel genetic material and values outside the original model range become available and increase transferability across years and genotypes but highlight that developmental stage and environment also likely influence these results.

We found that the wavelengths having significant contributions to models estimating nitrogen were related to chlorophyll and protein absorption features, which we expected given the contribution of these compounds to nitrogen levels in vegetative tissue [59]. We also found the wavelength region near $1400 \mathrm{~nm}$ was an important feature for predicting nitrogen at both leaf and canopy levels. In fresh leaves, this feature is found in a wavelength range strongly influenced by water absorption yet has previously been shown to contribute to spectral models estimating nitrogen in fresh and dry samples [51,66-70]. This outcome, coupled with those of other studies, suggests that, even while contained in a region strongly affected by water absorption, this feature plays an important role in nitrogen retrievals using spectral data.

Spectral data have been directly, through statistical approaches, or indirectly, via indices, used to estimate plant physiology, chemical composition, and water status $[21,24,28,29,32,33,37,54,58]$. Spectral data have also been used to assess withinplant nitrogen dynamics, including NUE and the sub-component NUpE [71]. NUpE is affected by several factors, including the vegetative stage of the plant, soil nitrogen content, and above-ground biomass [39]. While we found that spectral data did not directly estimate NUpE well, we could use spectrally predicted nitrogen as a reasonable surrogate for reference nitrogen when calculating NUpE. Although we found that bias in the relationship between NUpE calculated using either reference or spectrally predicted nitrogen was high, 
this can possibly be accounted for because the reference nitrogen for the traditionally calculated NUpE values was end-of-season nitrogen and had much lower nitrogen levels than the mid-season spectrally predicted nitrogen, which was much higher, explaining the overestimation of predicted NUpE values. One potential issue with modeling NUpE directly using mid-season foliar spectral data is the potential temporal disconnection with the nitrogen levels estimated during the mid-season and the yield data needed to calculate NUpE. One logistical drawback we encountered when trying to model NUpE using spectral data was a small sample size, which potentially did not provide a sufficient range of NUpE to characterize a relationship between spectral data and NUpE. The lack of a direct spectral relationship with $\mathrm{NUpE}$ contrasts with recent studies relating spectral data with NUE parameters [72,73]. Previous work has shown a significant correlation of canopy reflectance and the Maccioni index in the grain filling phase but highlighted the importance of large-plot research to study the relationship of vegetation indexes and nitrogen use dynamics [71]. It has also been suggested that heading is the optimal time to predict NUE using canopy reflectance, but the correlation between reflectance and NUE during the heading phase declined over a second season [63]. Regardless of the lack of a direct relationship between spectral data and $\mathrm{NUpE}$, the ability of spectrally estimated mid-season nitrogen to calculate $\mathrm{NUpE}$ shows that spectral data have considerable potential in monitoring nitrogen dynamics in wheat, especially in a breeding context.

\section{Conclusions}

Our results demonstrate that hyperspectral data, combined with chemometric modeling, is an effective method to monitor nitrogen dynamics in a diverse breeding population of wheat. We found reasonable transferability of models across years using full-range spectral data and improved model performance as we included greater genetic, developmental, and environmental variation of spectral and reference data. We also found promising model performance for canopy-based models, suggesting the potential for scaling measurements from leaves to fields using unmanned or manned aerial vehicles and highlighting the ability for whole-field monitoring of nitrogen management as a potential replacement for classical phenotyping approaches. Our research builds on the importance of including genotypic, phenotypic, and temporal variation in developing hyperspectral models estimating plant functional traits [30,31]. Moreover, we feel an important outcome of this research is the incorporation of hyperspectral data into crop nitrogen management and plant breeding for enhanced NUE. Outcomes of this work highlight the potential of hyperspectral data for precision nitrogen assessment in crops in both management and breeding contexts.

Author Contributions: Conceptualization, R.P.-D., L.C. and J.J.C.; methodology, R.P.-D., B.R., L.C., M.M. and J.J.C.; validation, R.P.-D. and J.J.C.; formal analysis, R.P.-D. and J.J.C.; investigation, R.P.-D. and J.J.C.; resources, J.J.C. and M.M.; data curation, R.P.-D.; writing—original draft preparation, R.P.-D.; writing—review and editing, R.P.-D., B.R., L.C., M.M. and J.J.C.; supervision, J.J.C.; project administration, J.J.C.; funding acquisition, J.J.C. All authors have read and agreed to the published version of the manuscript.

Funding: This work was supported by USDA NIFA Hatch awards IND011490 to J.J.C. and 1013073 to M.M.

Acknowledgments: We would like to thank Allie Duffy, Aimee Jasmine Stramowski, Anupreet Saini, Hanna Quellhorst, Kirsten Brichler, Marguerite Bolt, and Taylor Nelson for assistance with field collections.

Conflicts of Interest: The authors declare no conflict of interest. The funders had no role in the design of the study; in the collection, analyses, or interpretation of data; in the writing of the manuscript, or in the decision to publish the results. 


\section{Appendix A}

Table A1. Detailed soil characteristics of the experimental plots.

\begin{tabular}{ccc}
\hline Components & Plot 5 North & Plot 5 South \\
\hline Phosphorus (Bray P1lbs/acre) & 43 & 53 \\
\hline Potassium (pounds/acre) & 195 & 188 \\
\hline Calcium (pounds/acre) & 2326 & 2214 \\
\hline Magnesium (pounds/acre) & 715 & 621 \\
\hline Base Sat'n (\%) & 97 & 100 \\
\hline Calcium Sat'n (\%) & 62 & 66 \\
\hline Ca/Mg Ratio & 2 & 2.2 \\
\hline CEC (meq/100 g) & 11.09 & 9.95 \\
\hline Potassium Sat' $\mathbf{n}(\%)$ & 2.52 & 2.71 \\
\hline Magnesium Sat'n (\%) & 31 & 30 \\
\hline Mg/K Ratio & 12.5 & 11.2 \\
\hline pH & 6.93 & 70 \\
\hline Lime Index & 69.73 & \\
\hline
\end{tabular}

\section{Appendix B}

Table A2. List of wheat winter lines used in both years of experiments with respective yield indication. Wheat lines: 2017-2017 dataset; 2018-2018 dataset. Specific information on cultivar yield responses to variable fertilizer levels can be found in [38]. Copyright $\odot 2020$ Russell, Guzman and Mohammadi. This is an open-access article distributed under the terms of the Creative Commons Attribution License (CC BY). The use, distribution or reproduction in other forums is permitted, provided the original author(s) and the copyright owner(s) are credited and that the original publication in this journal is cited, in accordance with accepted academic practice. No use, distribution or reproduction is permitted which does not comply with these terms.

\begin{tabular}{|c|c|}
\hline Dataset & Wheat Line ID (Purdue ID) \\
\hline \multirow{4}{*}{2017} & 04606RA1-7-1-4 (PU01) \\
\hline & 053A1-2-5-3-5 (PU02) \\
\hline & 10101RA1-6-2 (PU26) \\
\hline & 11407A1-6 (PU24) \\
\hline \multirow{10}{*}{2018} & 0175A1-31-4-1 (PU17) \\
\hline & 03549A1-18-25-4 (PU05) \\
\hline & 04606RA1-7-1 (PU07) \\
\hline & 04606RA1-7-1-4 (PU01) \\
\hline & 04606RA1-7-1-6 (PU23) \\
\hline & 04719A1-16-1-1-47-4 (PU19) \\
\hline & 05247A1-7-3-29 (PU10) \\
\hline & 05247A1-7-3-98 (PU08) \\
\hline & 05247A-7-7-3-1 (PU25) \\
\hline & 05251A1-1-77-16-3 (PU22) \\
\hline
\end{tabular}


Table A2. Cont.

\begin{tabular}{|c|c|}
\hline Dataset & Wheat Line ID (Purdue ID) \\
\hline & 0537A1-3-12-1 (PU14) \\
\hline & 053A1-2-5-3-5-3 (PU02) \\
\hline & 0566A1-3-1-48 (PU09) \\
\hline & 0570A1-2-39-2-4 (PU06) \\
\hline & 0570A1-8-5-1 (PU03) \\
\hline & 057RA1-8-5-3 (PU13) \\
\hline & 057RA1-8-5-33 (PU11) \\
\hline & 06497A1-7-3 (PU21) \\
\hline & 07117B1-29-7-9-9-4-3-6-3 (PU29) \\
\hline & 0722A1-1-1-7 (PU04) \\
\hline & 07469A1-6-1-1 (PU18) \\
\hline & 0762A1-2-8 (PU15) \\
\hline & 08334A1-31 (PU12) \\
\hline & 10101RA1-6-2 (PU26) \\
\hline & 10221A1-8-1 (PU27) \\
\hline & 10222A1-9-2 (PU30) \\
\hline & 1041RB1-10 (PU16) \\
\hline & 10447A1-5 (PU28) \\
\hline & 10565C1-1 (PU20) \\
\hline & 11407A1-6 (PU24) \\
\hline & CHECK-P25R40 \\
\hline & CHECK-P25R62 \\
\hline
\end{tabular}

\section{Appendix C}

Table A3. Specific absorption bands related to plant chlorophyll a and b combined, chlorophyll a, or chlorophyll b and protein and the respective absorption mechanisms described in literature (Curran et al., 1989; Gitelson et al., 1995; Datt et al., 1998; Curran et al., 2001; Kumar et al., 2005; Berger et al., 2020) [19,59,73-76].

\begin{tabular}{cccc}
\hline Chemical & WL Highest Peak & Absorption Mechanisms & Literature Described the WL \\
\hline Chlorophyll a & 420 & Electron transition & Kumar et al., 2005 \\
Chlorophyll a & 430 & Electron transition & Curran et al., 1989 \\
Chlorophyll b & 435 & Electron transition & Kumar et al., 2005 \\
Chlorophyll b & 460 & Electron transition & Kumar et al., 1989 2005 \\
Chlorophyll a & 490 & Electron transition & Curran et al., 2001 \\
Chlorophyll & 530 & Electron transition & Curran et al., 2001 \\
Chlorophyll a & 550 & Electron transition & Curran et al., 1989 \\
Chlorophyll & 630 & Electron transition & Kumar et al., \\
Chlorophyll b & 640 & Electron transition & 1998 and Gitelson et al., \\
Chlorophyll b & 643 & Electron transition & Electron transition \\
Chlorophyll a & 660 & Electron transition & Curran et al., 1989; Kumar et al., 2005 \\
Chlorophyll & 675 & Not described 1998 \\
Chlorophyll & 700 & C-H stretch, 3rd overtone & Curran et al., 2001; Gitelson et al., 1995 \\
Protein & 910 & N-H stretch & Curran et al., 1989 \\
Protein & 1020 & &
\end{tabular}


Table A3. Cont.

\begin{tabular}{|c|c|c|c|}
\hline Chemical & WL Highest Peak & Absorption Mechanisms & Literature Described the WL \\
\hline Protein & 1500 & Not described & Kumar et al., 2005 \\
\hline Protein & 1510 & N-H stretch, 1st overtone & Curran et al., 1989 \\
\hline Protein & 1520 & N-H stretch, 1st overtone & Berger et al., 2020 \\
\hline Protein & 1680 & C-H strecth, 1st overtone & Kumar et al., 2005 \\
\hline Protein & 1690 & C-H strecth, 1st overtone & Berger et al., 2020 \\
\hline Protein & 1730 & C-H stretch & Kumar et al., 2005 \\
\hline Protein & 1940 & O-H strech, O-H deformation & Curran et al., 1989; Kumar et al., 2005 \\
\hline Protein & 1960 & $\mathrm{~N}-\mathrm{H}$ assymmetry & Berger et al., 2020 \\
\hline Protein & 1980 & $\mathrm{~N}-\mathrm{H}$ assymmetry & Curran et al., 1989 \\
\hline Protein & 2050 & $\mathrm{~N}-\mathrm{H}$ stretch, $\mathrm{N}=\mathrm{H}$ rotation & Kumar et al., 2005 \\
\hline Protein & 2060 & $\mathrm{~N}-\mathrm{H}$ stretch, $\mathrm{N}=\mathrm{H}$ rotation & Curran et al., 1989 \\
\hline Protein & 2130 & N-H stretch & Curran et al., 1989 \\
\hline Protein & 2170 & Not described & Kumar et al., 2005 \\
\hline Protein & 2180 & $\begin{array}{l}\text { N-H rotation, C-H stretch, } \\
\text { C-O stretch, } \mathrm{C}=\mathrm{O} \text { stretch }\end{array}$ & Curran et al., 1989 \\
\hline Protein & 2200 & $\begin{array}{l}\text { N-H rotation, } \mathrm{C}-\mathrm{H} \text { stretch, } \\
\mathrm{C}-\mathrm{O} \text { stretch, } \mathrm{C}=\mathrm{O} \text { stretch }\end{array}$ & Berger et al., 2020 \\
\hline Protein & 2240 & C-H stretch & Curran et al., 1989 \\
\hline Protein & 2270 & C-H stretch & Berger et al., 2020 \\
\hline Protein & 2290 & $\begin{array}{c}\mathrm{C}-\mathrm{H} \text { rotation, } \mathrm{C}=\mathrm{O} \text { stretch, } \\
\mathrm{N}-\mathrm{H} \text { stretch }\end{array}$ & Kumar et al., 2005 \\
\hline Protein & 2300 & $\begin{array}{c}\mathrm{C}-\mathrm{H} \text { rotation, } \mathrm{C}=\mathrm{O} \text { stretch, } \\
\mathrm{N}-\mathrm{H} \text { stretch }\end{array}$ & Curran et al., 1989 \\
\hline Protein & 2350 & $\begin{array}{c}\mathrm{CH} 2 \text { rotation, } \mathrm{C}-\mathrm{H} \\
\text { deformation }\end{array}$ & Curran et al., 1989 \\
\hline
\end{tabular}

\section{Appendix D}

Table A4. Standardized coefficient values of wavelengths associated with chlorophyll a and b combined, chlorophyll a, or chlorophyll b, and protein absorption feature for 2017 and multi-year models at both leaf and canopy levels. Bold values, standardized coefficient value within the top 30 highest standardized coefficients. NA, wavelength removed from the canopy data.

\begin{tabular}{|c|c|c|c|c|c|}
\hline \multirow[b]{2}{*}{ WL Highest Peak } & \multirow[b]{2}{*}{ Chemical } & \multicolumn{2}{|c|}{2017 Models } & \multicolumn{2}{|c|}{ Multi-Year Models } \\
\hline & & Leaf Level & Canopy Level & Leaf Level & Canopy Level \\
\hline 420 & Chlorophyll a & 0.42 & 0.09 & 0.69 & 0.09 \\
\hline 430 & Chlorophyll a & 0.29 & 0.05 & 0.59 & 0.08 \\
\hline 435 & Chlorophyll b & 0.26 & 0.05 & 0.57 & 0.09 \\
\hline 460 & Chlorophyll b & 0.2 & 0.05 & 0.33 & 0.09 \\
\hline 490 & Chlorophyll a & 0.19 & 0.06 & 0.21 & 0.10 \\
\hline 530 & Chlorophyll & 0.37 & 0.08 & 0.58 & 0.13 \\
\hline 550 & Chlorophyll a & 0.31 & 0.12 & 0.38 & 0.20 \\
\hline 630 & Chlorophyll & 0.05 & 0.06 & 0.10 & 0.13 \\
\hline 640 & Chlorophyll b & 0.06 & 0.05 & 0.13 & 0.11 \\
\hline 643 & Chlorophyll b & 0.06 & 0.04 & 0.13 & 0.10 \\
\hline 660 & Chlorophyll a & 0.06 & 0.03 & 0.15 & 0.07 \\
\hline 675 & Chlorophyll & 0.14 & 0.14 & 0.31 & 0.21 \\
\hline 700 & Chlorophyll & 0.38 & 0.25 & 0.58 & 0.32 \\
\hline 910 & Protein & 0.1 & 0.05 & 0.15 & 0.11 \\
\hline 1020 & Protein & 0.05 & 0.04 & 0.13 & 0.06 \\
\hline 1500 & Protein & 0.05 & 0.01 & 0.05 & 0.02 \\
\hline 1510 & Protein & 0.03 & 0.01 & 0.05 & 0.02 \\
\hline 1520 & Protein & 0.03 & 0.01 & 0.04 & 0.01 \\
\hline 1680 & Protein & 0.02 & 0.01 & 0.05 & 0.01 \\
\hline 1690 & Protein & 0.02 & 0.01 & 0.05 & 0.01 \\
\hline
\end{tabular}


Table A4. Cont.

\begin{tabular}{|c|c|c|c|c|c|}
\hline \multirow[b]{2}{*}{ WL Highest Peak } & \multirow[b]{2}{*}{ Chemical } & \multicolumn{2}{|c|}{2017 Models } & \multicolumn{2}{|c|}{ Multi-Year Models } \\
\hline & & Leaf Level & Canopy Level & Leaf Level & Canopy Level \\
\hline 1730 & Protein & 0.04 & 0.01 & 0.06 & 0.01 \\
\hline 1940 & Protein & 0.05 & NA & 0.08 & NA \\
\hline 1960 & Protein & 0.06 & NA & 0.10 & NA \\
\hline 1980 & Protein & 0.07 & NA & 0.11 & NA \\
\hline 2050 & Protein & 0.16 & 0.03 & 0.17 & 0.05 \\
\hline 2060 & Protein & 0.17 & 0.03 & 0.20 & 0.05 \\
\hline 2130 & Protein & 0.07 & 0.01 & 0.18 & 0.02 \\
\hline 2170 & Protein & 0.05 & 0.01 & 0.12 & 0.04 \\
\hline 2180 & Protein & 0.03 & 0.01 & 0.10 & 0.03 \\
\hline 2200 & Protein & 0.03 & 0.01 & 0.07 & 0.03 \\
\hline 2240 & Protein & 0.08 & 0.03 & 0.14 & 0.05 \\
\hline 2270 & Protein & 0.08 & 0.03 & 0.14 & 0.04 \\
\hline 2290 & Protein & 0.08 & 0.03 & 0.15 & 0.04 \\
\hline 2300 & Protein & 0.09 & 0.03 & 0.14 & 0.04 \\
\hline 2350 & Protein & 0.13 & 0.03 & 0.15 & 0.05 \\
\hline
\end{tabular}

Table A5. Variable importance for the projection (VIP) values of wavelengths associated with chlorophyll a and b combined, chlorophyll a, or chlorophyll b, and protein absorption feature for 2017 and multi-year models at both leaf and canopy levels. Bold values, VIP $\geq 0.8$. NA, wavelength removed from the canopy data.

\begin{tabular}{|c|c|c|c|c|c|}
\hline \multirow[b]{2}{*}{ Wavelength (nm) } & \multirow[b]{2}{*}{ Chemicall } & \multicolumn{2}{|c|}{2017 Models } & \multicolumn{2}{|c|}{ Multi-Year Models } \\
\hline & & Leaf Level & Canopy Level & Leaf Level & Canopy Level \\
\hline 420 & Chlorophyll a & 0.8 & 1.6 & 0.8 & 1.6 \\
\hline 430 & Chlorophyll a & 0.9 & 1.6 & 0.9 & 1.6 \\
\hline 435 & Chlorophyll b & 1.0 & 1.7 & 1.0 & 1.7 \\
\hline 460 & Chlorophyll b & 1.1 & 1.7 & 1.1 & 1.7 \\
\hline 490 & Chlorophyll a & 1.5 & 1.7 & 1.5 & 1.7 \\
\hline 530 & Chlorophyll & 1.9 & 1.4 & 1.9 & 1.4 \\
\hline 550 & Chlorophyll a & 1.6 & 1.7 & 1.6 & 1.7 \\
\hline 630 & Chlorophyll & 1.1 & 1.4 & 1.4 & 1.4 \\
\hline 640 & Chlorophyll b & 1.1 & 1.2 & 1.2 & 1.2 \\
\hline 643 & Chlorophyll b & 1.2 & 1.2 & 1.2 & 1.2 \\
\hline 660 & Chlorophyll a & 1.3 & 1.0 & 1.3 & 0.9 \\
\hline 675 & Chlorophyll & 1.5 & 1.2 & 1.5 & 1.2 \\
\hline 700 & Chlorophyll & 1.6 & 1.4 & 1.6 & 1.4 \\
\hline 910 & Protein & 0.7 & 0.6 & 0.7 & 0.7 \\
\hline 1020 & Protein & 0.8 & 0.4 & 0.9 & 0.4 \\
\hline 1500 & Protein & 1.0 & 0.6 & 1.0 & 0.7 \\
\hline 1510 & Protein & 1.0 & 0.6 & 1.0 & 0.7 \\
\hline 1520 & Protein & 1.0 & 0.6 & 1.0 & 0.6 \\
\hline 1680 & Protein & 0.9 & 1.1 & 0.9 & 1.1 \\
\hline 1690 & Protein & 0.9 & 1.2 & 0.9 & 1.1 \\
\hline 1730 & Protein & 1.0 & 0.9 & 1.0 & 0.9 \\
\hline 1940 & Protein & 0.9 & NA & 0.9 & NA \\
\hline 1960 & Protein & 1.1 & NA & 1.0 & NA \\
\hline 1980 & Protein & 1.1 & NA & 1.0 & NA \\
\hline 2050 & Protein & 0.9 & 0.7 & 0.9 & 0.7 \\
\hline 2060 & Protein & 0.9 & 0.7 & 1.0 & 0.7 \\
\hline 2130 & Protein & 0.8 & 0.3 & 0.8 & 0.4 \\
\hline 2170 & Protein & 0.6 & 0.2 & 0.7 & 0.3 \\
\hline 2180 & Protein & 0.6 & 0.2 & 0.6 & 0.3 \\
\hline 2200 & Protein & 0.5 & 0.2 & 0.6 & 0.3 \\
\hline 2240 & Protein & 0.9 & 0.7 & 0.9 & 0.8 \\
\hline 2270 & Protein & 0.7 & 0.4 & 0.7 & 0.4 \\
\hline 2290 & Protein & 0.6 & 0.3 & 0.6 & 0.3 \\
\hline 2300 & Protein & 0.7 & 0.3 & 0.6 & 0.3 \\
\hline 2350 & Protein & 0.7 & 0.3 & 0.6 & 0.3 \\
\hline
\end{tabular}


Table A6. Top 30 standardized coefficient values and their respective wavelength ranges from 2017 leaf and canopy models. The coefficients values displayed in this table represent the average standardized coefficient value every 30nm, as described by the wavelength range (WL Range $(\mathrm{nm})$ ). Colors highlighting the three main areas of the full-spectral range: green, visible (VIS); orange, near-infrared (NIR); and red, short-wave infrared (SWIR).

2017 Models

Leaf Level Canopy Level

WL Range (nm)

Coefficient

WL Range (nm)

Coefficient

\begin{tabular}{|c|c|c|c|c|c|c|c|}
\hline 400 & - & 429 & 0.51 & 400 & - & 429 & 0.10 \\
\hline 430 & - & 459 & 0.21 & 430 & - & 459 & 0.06 \\
\hline 460 & - & 489 & 0.18 & 460 & - & 489 & 0.06 \\
\hline 490 & - & 519 & 0.23 & 490 & - & 519 & 0.07 \\
\hline 520 & - & 549 & 0.40 & 520 & - & 549 & 0.08 \\
\hline 550 & - & 579 & 0.21 & 550 & - & 579 & 0.16 \\
\hline 670 & - & 699 & 0.28 & 580 & - & 609 & 0.12 \\
\hline 700 & - & 729 & 0.33 & 610 & - & 639 & 0.08 \\
\hline 760 & - & 789 & 0.12 & 670 & - & 699 & 0.22 \\
\hline 790 & - & 819 & 0.12 & 700 & - & 729 & 0.34 \\
\hline 910 & - & 939 & 0.13 & 730 & - & 759 & 0.57 \\
\hline 940 & - & 969 & 0.14 & 760 & - & 789 & 0.07 \\
\hline 970 & - & 999 & 0.41 & 790 & - & 819 & 0.11 \\
\hline 1120 & - & 1149 & 0.09 & 820 & - & 849 & 0.09 \\
\hline 1300 & - & 1329 & 0.11 & 850 & - & 879 & 0.08 \\
\hline 1330 & - & 1359 & 0.15 & 880 & - & 909 & 0.05 \\
\hline 1360 & - & 1389 & 0.16 & 910 & - & 939 & 0.08 \\
\hline 1390 & - & 1419 & 0.13 & 940 & - & 969 & 0.08 \\
\hline 1420 & - & 1449 & 0.13 & 970 & - & 999 & 0.06 \\
\hline 1450 & - & 1479 & 0.11 & 1000 & - & 1029 & 0.04 \\
\hline 1870 & - & 1899 & 0.28 & 1030 & - & 1059 & 0.05 \\
\hline 1900 & - & 1929 & 0.11 & 1060 & - & 1089 & 0.04 \\
\hline 1990 & - & 2019 & 0.11 & 1120 & - & 1149 & 0.04 \\
\hline 2020 & - & 2049 & 0.14 & 1150 & - & 1179 & 0.04 \\
\hline 2050 & - & 2079 & 0.18 & 1240 & - & 1269 & 0.04 \\
\hline 2230 & - & 2259 & 0.09 & 1330 & - & 1359 & 0.05 \\
\hline 2290 & - & 2319 & 0.09 & 1360 & - & 1389 & 0.08 \\
\hline 2320 & - & 2349 & 0.12 & 1390 & - & 1419 & 0.14 \\
\hline 2350 & - & 2379 & 0.11 & 1420 & - & 1449 & 0.07 \\
\hline 2380 & - & 2400 & 0.13 & 2370 & - & 2400 & 0.05 \\
\hline
\end{tabular}


Table A7. Variable importance for the projection (VIP) values $\geq 0.82017$ and multi-year models at both leaf and canopy levels. The VIP values displayed in this table represent the average VIP value after averaging VIP data every 30nm, as described by the wavelength range (WL Range (nm)). Colors highlighting the three main areas of the full-spectral range: green, visible (VIS); orange, near-infrared (NIR); and red, short-wave infrared (SWIR).

\begin{tabular}{|c|c|c|c|c|c|c|c|c|c|c|c|c|c|c|}
\hline \multicolumn{8}{|c|}{2017 Model } & \multicolumn{7}{|c|}{ Multi-Year Models } \\
\hline \multicolumn{4}{|c|}{ Leaf Level } & \multicolumn{4}{|c|}{ Canopy Level } & \multicolumn{4}{|c|}{ Leaf Level } & \multicolumn{3}{|c|}{ Canopy Level } \\
\hline \multicolumn{3}{|c|}{ WL Range (nm) } & \multirow{2}{*}{$\begin{array}{c}\mathrm{VIP} \geq \mathbf{0 . 8} \\
1.1\end{array}$} & \multicolumn{3}{|c|}{ WL Range (nm) } & \multirow{2}{*}{$\frac{\mathrm{VIP} \geq \mathbf{0 . 8}}{1.6}$} & \multicolumn{3}{|c|}{ WL Range (nm) } & \multirow{2}{*}{$\begin{array}{c}\mathrm{VIP} \geq \mathbf{0 . 8} \\
1.1\end{array}$} & \multicolumn{2}{|c|}{ WL Range (nm) } & \multirow{2}{*}{$\frac{\mathrm{VIP} \geq \mathbf{0 . 8}}{1.5}$} \\
\hline 430 & - & 459 & & 400 & - & 429 & & 430 & - & 459 & & 400 & 429 & \\
\hline 460 & - & 489 & 1.2 & 430 & - & 459 & 1.7 & 460 & - & 489 & 1.2 & 430 & 459 & 1.7 \\
\hline 490 & - & 519 & 1.9 & 460 & - & 489 & 1.7 & 490 & - & 519 & 1.9 & 460 & 489 & 1.7 \\
\hline 520 & - & 549 & 1.9 & 490 & - & 519 & 1.6 & 520 & - & 549 & 1.9 & 490 & 519 & 1.6 \\
\hline 550 & - & 579 & 1.4 & 520 & - & 549 & 1.4 & 550 & - & 579 & 1.3 & 520 & 549 & 1.4 \\
\hline 580 & - & 609 & 1.2 & 550 & - & 579 & 1.7 & 580 & - & 609 & 1.2 & 550 & 579 & 1.7 \\
\hline 610 & - & 639 & 1.1 & 580 & - & 609 & 1.6 & 610 & - & 639 & 1.1 & 580 & 609 & 1.7 \\
\hline 640 & - & 669 & 1.3 & 610 & - & 639 & 1.5 & 640 & - & 669 & 1.3 & 610 & 639 & 1.5 \\
\hline 670 & - & 699 & 1.6 & 640 & - & 669 & 0.9 & 670 & - & 699 & 1.6 & 640 & 669 & 0.8 \\
\hline 700 & - & 729 & 1.7 & 670 & - & 699 & 1.4 & 700 & - & 729 & 1.7 & 670 & 699 & 1.4 \\
\hline 730 & - & 759 & 1.8 & 700 & - & 729 & 1.4 & 730 & - & 759 & 2.0 & 700 & 729 & 1.4 \\
\hline 760 & - & 789 & 1.1 & 730 & - & 759 & 1.7 & 760 & - & 789 & 1.1 & 730 & 759 & 1.7 \\
\hline 790 & - & 819 & 1.1 & 760 & - & 789 & 1.0 & 790 & - & 819 & 1.1 & 760 & 789 & 1.0 \\
\hline 820 & - & 849 & 1.0 & 790 & - & 819 & 1.4 & 820 & - & 849 & 1.0 & 790 & 819 & 1.4 \\
\hline 850 & - & 879 & 0.9 & 820 & - & 849 & 1.5 & 850 & - & 879 & 0.9 & 820 & 849 & 1.5 \\
\hline 1000 & - & 1029 & 0.8 & 850 & - & 879 & 1.4 & 1000 & - & 1029 & 0.9 & 850 & 879 & 1.3 \\
\hline 1030 & - & 1059 & 0.8 & 880 & - & 909 & 0.8 & 1030 & - & 1059 & 0.8 & 880 & 909 & 0.8 \\
\hline 1120 & - & 1149 & 0.9 & 1060 & - & 1089 & 1.4 & 1090 & - & 1119 & 0.8 & 1060 & 1089 & 1.4 \\
\hline 1270 & - & 1299 & 0.8 & 1210 & - & 1239 & 1.4 & 1120 & - & 1149 & 0.9 & 1210 & 1239 & 1.4 \\
\hline 1300 & - & 1329 & 0.9 & 1240 & - & 1269 & 1.3 & 1210 & - & 1239 & 0.8 & 1240 & 1269 & 1.2 \\
\hline 1330 & - & 1359 & 0.9 & 1270 & - & 1299 & 1.1 & 1270 & - & 1299 & 0.8 & 1270 & 1299 & 1.2 \\
\hline 1360 & - & 1389 & 0.9 & 1420 & - & 1449 & 0.8 & 1300 & - & 1329 & 0.9 & 1420 & 1449 & 0.8 \\
\hline 1390 & - & 1419 & 1.1 & 1600 & - & 1629 & 1.2 & 1330 & - & 1359 & 0.9 & 1600 & 1629 & 1.2 \\
\hline 1420 & - & 1449 & 1.0 & 1660 & - & 1689 & 1.2 & 1360 & - & 1389 & 0.9 & 1660 & 1689 & 1.1 \\
\hline 1450 & - & 1479 & 1.0 & 1690 & - & 1719 & 1.1 & 1390 & - & 1419 & 1.1 & 1690 & 1719 & 1.1 \\
\hline 1480 & - & 1509 & 1.0 & 1720 & - & 1749 & 0.9 & 1420 & - & 1449 & 1.0 & 1720 & 1749 & 0.9 \\
\hline 1510 & - & 1539 & 1.0 & & & & & 1450 & - & 1479 & 0.9 & 2040 & 2069 & 0.8 \\
\hline 1540 & - & 1569 & 0.9 & & & & & 1480 & - & 1509 & 1.0 & 2220 & 2249 & 0.8 \\
\hline 1570 & - & 1599 & 0.9 & & & & & 1510 & - & 1539 & 0.9 & & & \\
\hline 1600 & - & 1629 & 0.8 & & & & & 1540 & - & 1569 & 0.9 & & & \\
\hline 1660 & - & 1689 & 0.9 & & & & & 1570 & - & 1599 & 0.9 & & & \\
\hline 1690 & - & 1719 & 1.1 & & & & & 1600 & - & 1629 & 0.9 & & & \\
\hline 1720 & - & 1749 & 0.9 & & & & & 1660 & - & 1689 & 0.9 & & & \\
\hline 1750 & - & 1779 & 0.9 & & & & & 1690 & - & 1719 & 1.0 & & & \\
\hline 1780 & - & 1809 & 0.8 & & & & & 1720 & - & 1749 & 0.9 & & & \\
\hline 1810 & - & 1839 & 0.9 & & & & & 1750 & - & 1779 & 0.9 & & & \\
\hline 1840 & - & 1869 & 1.0 & & & & & 1780 & - & 1809 & 0.8 & & & \\
\hline 1870 & - & 1899 & 1.1 & & & & & 1810 & - & 1839 & 0.9 & & & \\
\hline 1900 & - & 1929 & 0.9 & & & & & 1840 & - & 1869 & 0.9 & & & \\
\hline 1930 & - & 1959 & 1.0 & & & & & 1870 & - & 1899 & 1.1 & & & \\
\hline
\end{tabular}


Table A7. Cont.

\begin{tabular}{|c|c|c|c|c|c|c|c|c|c|c|c|}
\hline \multicolumn{6}{|c|}{2017 Model } & \multicolumn{6}{|c|}{ Multi-Year Models } \\
\hline \multicolumn{4}{|c|}{ Leaf Level } & \multicolumn{2}{|c|}{ Canopy Level } & \multicolumn{4}{|c|}{ Leaf Level } & \multicolumn{2}{|c|}{ Canopy Level } \\
\hline \multicolumn{3}{|c|}{ WL Range (nm) } & \multirow{2}{*}{$\begin{array}{c}\mathbf{V I P} \geq \mathbf{0 . 8} \\
1.1\end{array}$} & \multirow[t]{2}{*}{ WL Range (nm) } & \multirow[t]{2}{*}{$\mathrm{VIP} \geq \mathbf{0 . 8}$} & \multicolumn{3}{|c|}{ WL Range (nm) } & \multirow{2}{*}{$\begin{array}{c}\mathbf{V I P} \geq \mathbf{0 . 8} \\
0.9\end{array}$} & \multirow[t]{2}{*}{ WL Range (nm) } & \multirow[t]{2}{*}{$\mathrm{VIP} \geq 0.8$} \\
\hline 1960 & - & 1989 & & & & 1900 & - & 1929 & & & \\
\hline 1990 & - & 2019 & 1.1 & & & 1930 & - & 1959 & 1.0 & & \\
\hline 2020 & - & 2049 & 0.9 & & & 1960 & - & 1989 & 1.0 & & \\
\hline 2050 & - & 2079 & 0.9 & & & 1990 & - & 2019 & 1.0 & & \\
\hline 2080 & - & 2109 & 0.8 & & & 2020 & - & 2049 & 0.9 & & \\
\hline 2110 & - & 2139 & 0.8 & & & 2050 & - & 2079 & 1.0 & & \\
\hline \multirow[t]{4}{*}{2230} & - & 2259 & 1.0 & & & 2080 & - & 2109 & 0.8 & & \\
\hline & & & & & & 2110 & - & 2139 & 0.8 & & \\
\hline & & & & & & 2140 & - & 2169 & 0.8 & & \\
\hline & & & & & & 2230 & - & 2259 & 0.9 & & \\
\hline
\end{tabular}

Table A8. Top 30 standardized coefficient values and their respective wavelength ranges from multi-year leaf and canopy models. The coefficient values displayed in this table represent the average standardized coefficient value every $30 \mathrm{~nm}$, as described by the wavelength range (WL Range (nm)). Colors highlighting the three main areas of the full-spectral range: green, visible (VIS); orange, near-infrared (NIR); and red, short-wave infrared (SWIR).

\begin{tabular}{|c|c|c|c|c|c|c|c|}
\hline \multicolumn{8}{|c|}{ Multi-Year Models } \\
\hline \multirow{2}{*}{\multicolumn{3}{|c|}{$\begin{array}{l}\text { Leaf Level } \\
\text { WL Range (nm) }\end{array}$}} & \multirow{3}{*}{$\begin{array}{c}\text { Coefficient } \\
0.77\end{array}$} & \multicolumn{4}{|c|}{ Canopy Level } \\
\hline & & & & & WL Rang & & Coefficient \\
\hline 400 & - & 429 & & 400 & - & 429 & 0.10 \\
\hline 430 & - & 459 & 0.45 & 430 & - & 459 & 0.10 \\
\hline 460 & - & 489 & 0.23 & 460 & - & 489 & 0.09 \\
\hline 490 & - & 519 & 0.25 & 490 & - & 519 & 0.11 \\
\hline 520 & - & 549 & 0.64 & 520 & - & 549 & 0.14 \\
\hline 550 & - & 579 & 0.23 & 550 & - & 579 & 0.24 \\
\hline 640 & - & 669 & 0.16 & 580 & - & 609 & 0.20 \\
\hline 670 & - & 699 & 0.52 & 610 & - & 639 & 0.15 \\
\hline 700 & - & 729 & 0.40 & 670 & - & 699 & 0.31 \\
\hline 730 & - & 759 & 0.26 & 700 & - & 729 & 0.35 \\
\hline 760 & - & 789 & 0.15 & 730 & - & 759 & 0.54 \\
\hline 790 & - & 819 & 0.17 & 760 & - & 789 & 0.18 \\
\hline 910 & - & 939 & 0.18 & 790 & - & 819 & 0.11 \\
\hline 940 & - & 969 & 0.24 & 820 & - & 849 & 0.13 \\
\hline 970 & - & 999 & 0.51 & 850 & - & 879 & 0.08 \\
\hline 1000 & - & 1029 & 0.15 & 880 & - & 909 & 0.07 \\
\hline 1300 & - & 1329 & 0.16 & 910 & - & 939 & 0.17 \\
\hline 1330 & - & 1359 & 0.18 & 940 & - & 969 & 0.18 \\
\hline 1360 & - & 1389 & 0.30 & 970 & - & 999 & 0.12 \\
\hline 1390 & - & 1419 & 0.33 & 1030 & - & 1059 & 0.07 \\
\hline 1420 & - & 1449 & 0.27 & 1090 & - & 1119 & 0.08 \\
\hline 1450 & - & 1479 & 0.15 & 1120 & - & 1149 & 0.07 \\
\hline 1870 & - & 1899 & 0.15 & 1150 & - & 1179 & 0.07 \\
\hline 1900 & - & 1929 & 0.28 & 1330 & - & 1359 & 0.20 \\
\hline 2050 & - & 2079 & 0.22 & 1360 & - & 1389 & 0.14 \\
\hline 2110 & - & 2139 & 0.17 & 1390 & - & 1419 & 0.21 \\
\hline 2140 & - & 2169 & 0.19 & 1420 & - & 1449 & 0.08 \\
\hline 2230 & - & 2259 & 0.16 & 1780 & - & 2009 & 0.08 \\
\hline 2350 & - & 2379 & 0.16 & 2340 & - & 2369 & 0.07 \\
\hline 2380 & - & 2400 & 0.19 & 2370 & - & 2400 & 0.09 \\
\hline
\end{tabular}




\section{References}

1. Shiferaw, B.; Smale, M.; Braun, H.-J.; Duveiller, E.; Reynolds, M.; Muricho, G. Crops that feed the world Past successes and future challenges to the role played by wheat in global food security. Food Secur. 2013, 5, 291-317. [CrossRef]

2. FAO. GIEWS Crop Prospects and Food Situation. 2 July 2019. Available online: http://www.fao.org/documents/card/en/c/ca5 327en (accessed on 15 January 2020).

3. Phillips, B.S.; Norton, R. Global Wheat Production and Fertilizer Use. Better Crop. 2012, 96, 4-6.

4. Rose, G.J. Crop Production. Soil Sci. 1956, 81, 152. [CrossRef]

5. Li, G.; Yu, M.; Fang, T.; Cao, S.; Carver, B.F.; Yan, L. Vernalization requirement duration in winter wheat is controlled by T a VRN-A 1 at the protein level. Plant J. 2013, 76, 742-753. [CrossRef] [PubMed]

6. Dong, K.; Zhen, S.; Cheng, Z.; Cao, H.; Ge, P.; Yan, Y. Proteomic Analysis Reveals Key Proteins and Phosphoproteins upon Seed Germination of Wheat (Triticum aestivum L.). Front. Plant Sci. 2015, 6. [CrossRef] [PubMed]

7. Delogu, G.; Cattivelli, L.; Pecchioni, N.; De Falcis, D.; Maggiore, T.; Stanca, A. Uptake and agronomic efficiency of nitrogen in winter barley and winter wheat. Eur. J. Agron. 1998, 9, 11-20. [CrossRef]

8. Barbottin, A.; LeComte, C.; Bouchard, C.; Jeuffroy, M.-H. Nitrogen Remobilization during Grain Filling in Wheat: Genotypic and Environmental Effects. Crop. Sci. 2005, 45, 1141-1150. [CrossRef]

9. Robertson, G.; Vitousek, P.M. Nitrogen in Agriculture: Balancing the Cost of an Essential Resource. Annu. Rev. Environ. Resour. 2009, 34, 97-125. [CrossRef]

10. Garnett, T.; Plett, D.; Heuer, S.; Okamoto, M. Genetic approaches to enhancing nitrogen-use efficiency (NUE) in cereals: Challenges and future directions. Funct. Plant Biol. 2015, 42, 921. [CrossRef]

11. Heisey, P.W.; Norton, G. Fertilizers and other farm chemicals. In Handbook of Agricultural Economics; Evenson, R., Pingali, P., Eds.; Elsevier North Holland: Amsterdam, The Netherlands, 2007; Volume 3, pp. 2741-2777.

12. Wei, F.; Yan, Z.; Yongchao, T.; Weixing, C.; Xia, Y.; Yingxue, L. Monitoring leaf nitrogen accumulation in wheat with hyper-spectral remote sensing. Acta Ecol. Sin. 2008, 28, 23-32. [CrossRef]

13. Hitz, K.; Clark, A.J.; Van Sanford, D.A. Identifying nitrogen-use efficient soft red winter wheat lines in high and low nitrogen environments. Field Crop. Res. 2017, 200, 1-9. [CrossRef]

14. Moll, R.H.; Kamprath, E.J.; Jackson, W.A. Analysis and interpretation of factors which contribute to efficiency of nitrogenutilization. Agron. J. 1982, 74, 562-564. [CrossRef]

15. Kong, L.; Xie, Y.; Hu, L.; Feng, B.; Li, S. Remobilization of vegetative nitrogen to developing grain in wheat (Triticum aestivum L.). Field Crop. Res. 2016, 196, 134-144. [CrossRef]

16. Han, M.; Okamoto, M.; Beatty, P.H.; Rothstein, S.J.; Good, A.G. The Genetics of Nitrogen Use Efficiency in Crop Plants. Annu. Rev. Genet. 2015, 49, 269-289. [CrossRef]

17. Araus, J.L.; Kefauver, S.C.; Zaman-Allah, M.; Olsen, M.S.; Cairns, J. Translating High-Throughput Phenotyping into Genetic Gain. Trends Plant Sci. 2018, 23, 451-466. [CrossRef]

18. Roitsch, T.; Cabrera-Bosquet, L.; Fournier, A.; Ghamkhar, K.; Jiménez-Berni, J.; Pinto, F.; Ober, E.S. Review: New sensors and data-driven approaches-A path to next generation phenomics. Plant Sci. 2019, 282, 2-10. [CrossRef]

19. Curran, P.J. Remote sensing of foliar chemistry. Remote Sens. Environ. 1989, 30, 271-278. [CrossRef]

20. Cotrozzi, L.; Townsend, P.A.; Pellegrini, E.; Nali, C.; Couture, J.J. Reflectance spectroscopy: A novel approach to better understand and monitor the impact of air pollution on Mediterranean plants. Environ. Sci. Pollut. Res. 2017, 25, 8249-8267. [CrossRef]

21. Serbin, S.P.; Dillaway, D.N.; Kruger, E.L.; Townsend, P.A. Leaf optical properties reflect variation in photosynthetic metabolism and its sensitivity to temperature. J. Exp. Bot. 2011, 63, 489-502. [CrossRef] [PubMed]

22. Li, F.; Mistele, B.; Hu, Y.; Chen, X.; Schmidhalter, U. Reflectance estimation of canopy nitrogen content in winter wheat using optimised hyperspectral spectral indices and partial least squares regression. Eur. J. Agron. 2014, 52, 198-209. [CrossRef]

23. Féret, J.-B.; Berger, K.; de Boissieu, F.; Malenovský, Z. PROSPECT-PRO for estimating content of nitrogen-containing leaf proteins and other carbon-based constituents. Remote Sens. Environ. 2020, 252, 112173. [CrossRef]

24. Ollinger, S.V. Sources of variability in canopy reflectance and the convergent properties of plants. New Phytol. 2010, 189, 375-394. [CrossRef]

25. Couture, J.J.; Serbin, S.P.; Townsend, P.A. Spectroscopic sensitivity of real-time, rapidly induced phytochemical change in response to damage. New Phytol. 2013, 198, 311-319. [CrossRef]

26. Serbin, S.P.; Singh, A.; Desai, A.R.; Dubois, S.G.; Jablonski, A.D.; Kingdon, C.; Kruger, E.L.; Townsend, P. Remotely estimating photosynthetic capacity, and its response to temperature, in vegetation canopies using imaging spectroscopy. Remote Sens. Environ. 2015, 167, 78-87. [CrossRef]

27. Yuan, M.; Couture, J.J.; Townsend, P.A.; Ruark, M.D.; Bland, W.L. Spectroscopic Determination of Leaf Nitrogen Concentration and Mass Per Area in Sweet Corn and Snap Bean. Agron. J. 2016, 108, 2519-2526. [CrossRef]

28. Cotrozzi, L.; Couture, J.J.; Cavender-Bares, J.; Kingdon, C.; Fallon, B.; Pilz, G.; Pellegrini, E.; Nali, C.; A Townsend, P. Using foliar spectral properties to assess the effects of drought on plant water potential. Tree Physiol. 2017, 37, 1582-1591. [CrossRef] [PubMed]

29. Silva-Perez, V.; Molero, G.; Serbin, S.P.; Condon, A.G.; Reynolds, M.P.; Furbank, R.T.; Evans, J.R. Hyperspectral reflectance as a tool to measure biochemical and physiological traits in wheat. J. Exp. Bot. 2017, 69, 483-496. [CrossRef] [PubMed] 
30. Meacham-Hensold, K.; Montes, C.; Wu, J.; Guan, K.; Fu, P.; Ainsworth, E.A.; Pederson, T.; Moore, C.; Brown, K.L.; Raines, C.; et al. High-throughput field phenotyping using hyperspectral reflectance and partial least squares regression (PLSR) reveals genetic modifications to photosynthetic capacity. Remote Sens. Environ. 2019, 231, 111176. [CrossRef] [PubMed]

31. Bruning, B.; Berger, B.; Lewis, M.; Liu, H.; Garnett, T. Approaches, applications, and future directions for hyperspectral vegetation studies: An emphasis on yield-limiting factors in wheat. Plant Phenome J. 2020, 3, 1-22. [CrossRef]

32. Cotrozzi, L.; Peron, R.; Tuinstra, M.R.; Mickelbart, M.V.; Couture, J.J. Spectral Phenotyping of Physiological and Anatomical Leaf Traits Related with Maize Water Status. Plant Physiol. 2020, 184, 1363-1377. [CrossRef]

33. Campos-Medina, V.A.; Cotrozzi, L.; Stuart, J.J.; Couture, J.J. Spectral characterization of wheat functional trait responses to Hessian fly: Mechanisms for trait-based resistance. PLoS ONE 2019, 14, e219431. [CrossRef] [PubMed]

34. Tan, C.; Du, Y.; Zhou, J.; Wang, D.; Luo, M.; Zhang, Y.; Guo, W. Analysis of Different Hyperspectral Variables for Diagnosing Leaf Nitrogen Accumulation in Wheat. Front. Plant Sci. 2018, 9, 674. [CrossRef]

35. Liang, L.; Di, L.; Huang, T.; Wang, J.; Lin, L.; Wang, L.; Yang, M. Estimation of Leaf Nitrogen Content in Wheat Using New Hyperspectral Indices and a Random Forest Regression Algorithm. Remote Sens. 2018, 10, 1940. [CrossRef]

36. Duan, D.-D.; Zhao, C.-J.; Li, Z.-H.; Yang, G.-J.; Yang, W.-D. Estimating total leaf nitrogen concentration in winter wheat by canopy hyperspectral data and nitrogen vertical distribution. J. Integr. Agric. 2019, 18, 1562-1570. [CrossRef]

37. Yendrek, C.R.; Tomaz, T.; Montes, C.; Cao, Y.; Morse, A.M.; Brown, P.J.; McIntyre, L.; Leakey, A.D.; Ainsworth, E.A. HighThroughput Phenotyping of Maize Leaf Physiological and Biochemical Traits Using Hyperspectral Reflectance. Plant Physiol. 2016, 173, 614-626. [CrossRef]

38. Russell, B.; Guzman, C.; Mohammadi, M. Cultivar, Trait and Management System Selection to Improve Soft-Red Winter Wheat Productivity in the Eastern United States. Front. Plant Sci. 2020, 11. [CrossRef] [PubMed]

39. Muñoz-Huerta, R.F.; Guevara-Gonzalez, R.G.; Contreras-Medina, L.M.; Torres-Pacheco, I.; Prado-Olivarez, J.; Ocampo-Velazquez, R.V. A Review of Methods for Sensing the Nitrogen Status in Plants: Advantages, Disadvantages and Recent Advances. Sensors 2013, 13, 10823-10843. [CrossRef] [PubMed]

40. Dumas, J.B.A. Procedes de l'analyse Organic. Annales de Chimie et de Physique. Ann. Chem. Phys. 1831, $247,198-213$.

41. Wold, S.; Ruhe, A.; Wold, H.; Dunn, W. The collinearity problem in linear regression. The partial least squares (PLS) approach to generalized inverses. SIAM J. Sci. Stat. Comput. 1984, 5, 735-743. [CrossRef]

42. Wold, S.; Sjöström, M.; Eriksson, L. PLS-regression: A basic tool of chemometrics. Chemom. Intell. Lab. Syst. 2001, 58, 109-130. [CrossRef]

43. Grossman, Y.; Ustin, S.; Jacquemoud, S.; Sanderson, E.; Schmuck, G.; Verdebout, J. Critique of stepwise multiple linear regression for the extraction of leaf biochemistry information from leaf reflectance data. Remote Sens. Environ. 1996, 56, 182-193. [CrossRef]

44. Cotrozzi, L.; Lorenzini, G.; Nali, C.; Pellegrini, E.; Saponaro, V.; Hoshika, Y.; Arab, L.; Rennenberg, H.; Paoletti, E. Hyperspectral Reflectance of Light-Adapted Leaves Can Predict Both Dark- and Light-Adapted Chl Fluorescence Parameters, and the Effects of Chronic Ozone Exposure on Date Palm (Phoenix dactylifera). Int. J. Mol. Sci. 2020, 21, 6441. [CrossRef] [PubMed]

45. Bolster, K.L.; Martin, M.E.; Aber, J.D. Determination of carbon fraction and nitrogen concentration in tree foliage by near infrared reflectances: A comparison of statistical methods. Can. J. For. Res. 1996, 26, 590-600. [CrossRef]

46. Atzberger, C.; Guérif, M.; Baret, F.; Werner, W. Comparative analysis of three chemometric techniques for the spectroradiometric assessment of canopy chlorophyll content in winter wheat. Comput. Electron. Agric. 2010, 73, 165-173. [CrossRef]

47. Serbin, S.P.; Singh, A.; McNeil, B.E.; Kingdon, C.; Townsend, P. Spectroscopic determination of leaf morphological and biochemical traits for northern temperate and boreal tree species. Ecol. Appl. 2014, 24, 1651-1669. [CrossRef]

48. Couture, J.J.; Singh, A.; Rubert-Nason, K.F.; Serbin, S.; Lindroth, R.L.; Townsend, P. Spectroscopic determination of ecologically relevant plant secondary metabolites. Methods Ecol. Evol. 2016, 7, 1402-1412. [CrossRef]

49. Chen, S.; Hong, X.; Harris, C.J.; Sharkey, P.M. Sparse Modeling Using Orthogonal Forward Regression With PRESS Statistic and Regularization. IEEE Trans. Syst. Man Cybern. Part B (Cybern.) 2004, 34, 898-911. [CrossRef]

50. Wang, Z.; Chlus, A.; Geygan, R.; Ye, Z.; Zheng, T.; Singh, A.; Couture, J.J.; Cavender-Bares, J.; Kruger, E.L.; Townsend, P.A. Foliar functional traits from imaging spectroscopy across biomes in eastern North America. New Phytol. 2020, 228, 494-511. [CrossRef]

51. Cotrozzi, L.; Couture, J.J. Hyperspectral assessment of plant responses to multi-stress environments: Prospects for managing protected agrosystems. Plants People Planet 2019, 2, 244-258. [CrossRef]

52. Marchica, A.; Loré, S.; Cotrozzi, L.; Lorenzini, G.; Nali, C.; Pellegrini, E.; Remorini, D. Early Detection of Sage (Salvia officinalis L.) Responses to Ozone Using Reflectance Spectroscopy. Plants 2019, 8, 346. [CrossRef]

53. Yu, K.-Q.; Zhao, Y.-R.; Li, X.-L.; Shao, Y.-N.; Liu, F.; He, Y. Hyperspectral Imaging for Mapping of Total Nitrogen Spatial Distribution in Pepper Plant. PLoS ONE 2014, 9, e116205. [CrossRef] [PubMed]

54. Chong, I.-G.; Jun, C.-H. Performance of some variable selection methods when multicollinearity is present. Chemom. Intell. Lab. Syst. 2005, 78, 103-112. [CrossRef]

55. Acevedo, M.; Zurn, J.D.; Molero, G.; Singh, P.; He, X.; Aoun, M.; McCandless, L. The role of wheat in global food security. In Agricultural Development and Sustainable Intensification: Technology and Policy Challenges in the Face of Climate Change; Routledge: Abingdon, UK, 2018; pp. 81-110. [CrossRef]

56. Hawkesford, M.J. Reducing the reliance on nitrogen fertilizer for wheat production. J. Cereal Sci. 2013, 59, 276-283. [CrossRef] [PubMed] 
57. Yousfi, S.; Marin Peira, J.F.; De la Horra, G.R.; Ablanque, P.V.M. Remote Sensing: Useful Approach for Crop Nitrogen Management and Sustainable Agriculture. In Soil Managment and Plant Nutrition for susteinable Crop Production; IntechOpen: London, UK, 2019; pp. 1-12. [CrossRef]

58. Calzone, A.; Cotrozzi, L.; Remorini, D.; Lorenzini, G.; Nali, C.; Pellegrini, E. Oxidative stress assessment by a spectroscopic approach in pomegranate plants under a gradient of ozone concentrations. Environ. Exp. Bot. 2020, 182, 104309. [CrossRef]

59. Berger, K.; Verrelst, J.; Féret, J.-B.; Wang, Z.; Wocher, M.; Strathmann, M.; Danner, M.; Mauser, W.; Hank, T. Crop nitrogen monitoring: Recent progress and principal developments in the context of imaging spectroscopy missions. Remote Sens. Environ. 2020, 242, 111758. [CrossRef]

60. Li, H.; Zhang, Y.; Lei, Y.; Antoniuk, V.; Hu, C. Evaluating Different Non-Destructive Estimation Methods for Winter Wheat (Triticum aestivum L.) Nitrogen Status Based on Canopy Spectrum. Remote Sens. 2019, 12, 95. [CrossRef]

61. Homolová, L.; Malenovský, Z.; Clevers, J.G.; García-Santos, G.; Schaepman, M.E. Review of optical-based remote sensing for plant trait mapping. Ecol. Complex. 2013, 15, 1-16. [CrossRef]

62. Kokaly, R.F.; Asner, G.; Ollinger, S.; Martin, M.E.; Wessman, C.A. Characterizing canopy biochemistry from imaging spectroscopy and its application to ecosystem studies. Remote Sens. Environ. 2009, 113, S78-S91. [CrossRef]

63. Chapin, F.S.; Bloom, A.J.; Field, C.B.; Waring, R.H. Plant Responses to Multiple Environmental Factors. BioScience 1987, 37, 49-57. [CrossRef]

64. Ellis, R. The most abundant protein in the world. Trends Biochem. Sci. 1979, 4, 241-244. [CrossRef]

65. Ecarnot, M.; Compan, F.; Roumet, P. Assessing leaf nitrogen content and leaf mass per unit area of wheat in the field throughout plant cycle with a portable spectrometer. Field Crop. Res. 2013, 140, 44-50. [CrossRef]

66. Ge, Y.; Atefi, A.; Zhang, H.; Miao, C.; Ramamurthy, R.K.; Sigmon, B.; Yang, J.; Schnable, J.C. High-throughput analysis of leaf physiological and chemical traits with VIS-NIR-SWIR spectroscopy: A case study with a maize diversity panel. Plant Methods 2019, 15, 1-12. [CrossRef]

67. Mahajan, G.R.; Sahoo, R.N.; Pandey, R.N.; Gupta, V.K.; Kumar, D. Using hyperspectral remote sensing techniques to monitor nitrogen, phosphorus, sulphur and potassium in wheat (Triticum aestivum L.). Precis. Agric. 2014, 15, 499-522. [CrossRef]

68. Fourty, T.; Baret, F.; Jacquemoud, S.; Schmuck, G.; Verdebout, J. Leaf optical properties with explicit description of its biochemical composition: Direct and inverse problems. Remote Sens. Environ. 1996, 56, 104-117. [CrossRef]

69. Wang, J.; Chen, J.M.; Ju, W.; Qiu, F.; Zhang, Q.; Fang, M.; Chen, F. Limited Effects of Water Absorption on Reducing the Accuracy of Leaf Nitrogen Estimation. Remote Sens. 2017, 9, 291. [CrossRef]

70. Frels, K.; Guttieri, M.; Joyce, B.; Leavitt, B.; Baenziger, P.S. Evaluating canopy spectral reflectance vegetation indices to estimate nitrogen use traits in hard winter wheat. Field Crop. Res. 2018, 217, 82-92. [CrossRef]

71. Pavuluri, K.; Chim, B.K.; Griffey, C.A.; Reiter, M.S.; Balota, M.; Thomason, W.E. Canopy spectral reflectance can predict grain nitrogen use efficiency in soft red winter wheat. Precis. Agric. 2014, 16, 405-424. [CrossRef]

72. Nigon, T.; Yang, C.; Paiao, G.D.; Mulla, D.; Knight, J.; Fernández, F. Prediction of Early Season Nitrogen Uptake in Maize Using High-Resolution Aerial Hyperspectral Imagery. Remote Sens. 2020, 12, 1234. [CrossRef]

73. Gitelson, A.A.; Merzlyak, M.N. Signature Analysis of Leaf Reflectance Spectra: Algorithm Development for Remote Sensing of Chlorophyll. J. Plant Physiol. 1996, 148, 494-500. [CrossRef]

74. Datt, B. Remote Sensing of Chlorophyll a, Chlorophyll b, Chlorophyll a+b, and Total Carotenoid Content in Eucalyptus Leaves. Remote Sens. Environ. 1998, 66, 111-121. [CrossRef]

75. Curran, P.J.; Dungan, J.L.; Peterson, D.L. Estimating the foliar biochemical concentration of leaves with reflectance spectrometry: Testing the Kokaly and Clark methodologies. Remote Sens. Environ. 2001, 76, 349-359. [CrossRef]

76. Kumar, L.; Schmidt, K.; Dury, S.; Skidmore, A. Imaging Spectrometry and Vegetation Science. In Imaging Spectrom; Springer: Dordrecht, The Netherlands, 2006; Volume 4, pp. 111-155. [CrossRef] 